\title{
Paisagens e vivências na fronteira: De Castro Marim a Montalvão nos inícios do século XVI
}

\author{
Paisaje y vivencias en la frontera: De Castro Marim a \\ Montalvão a inicios del siglo XVI
}

\section{Border Landscape and Daily Life: From Castro Marim to Montalvão in the Early Sixteenth century}

\author{
Isabel VAZ DE FREITAS \\ Doutora em História, Professora Associada com Agregação da Universidade Portucalense. \\ Departamento de Turismo, Património e Cultura, Universidade Portucalense. Av. António Bernardino \\ de Almeida, 619, 4200-072 Porto (Portugal). \\ C. e.: ifc@upt.pt \\ ORCID: http://orcid.org/0000-0002-1277-3700 \\ Recibido: 19/02/2019. Aceptado: 15/04/2019. \\ Cómo citar: Freitas, Isabel Vaz de, «Paisagens e vivencias na fronteira: De Castro Marim a Montalvão \\ nos inícios do século XVI», Edad Media. Revista de Historia, 2019, nº 20, pp. 244-280. \\ DOI: https://doi.org/10.24197/em.20.2019.244-280
}

\begin{abstract}
Resumen: Las fronteras que separan los reinos peninsulares en la Edad Media se determinaron como resultado de la Reconquista, de la voluntad política y el establecimiento de pobladores que en los diferentes territorios fueron creando dinámicas más localizadas. El paisaje fue determinante en la creación de vínculos territoriales o de separaciones impuestas por locales de una geografía adversa. En relación con las facilidades o dificultades de contacto y con el desarrollo de las actividades económicas, las comunidades locales fueron creando relaciones familiares, de paz y de amistad, que alternaban con momentos de conflicto y de resistencias. En el siglo XVI, los viajes de Afonso Mendes de Resende y de Duarte de Armas, nos permiten entender la organización cultural, social, económica y política del espacio de frontera y de las relaciones cotidianas establecidas en torno a esa línea, siempre presente en la memoria y en las demarcaciones del territorio
\end{abstract}

Palabras clave: Frontera; Vida cotidiana; Paisaje; Economía; Sociedad.

\begin{abstract}
The frontiers between the two Peninsular kingdoms were set up in the Middle Ages in the aftermath of the Reconquista out of political will and consolidated by the settlement of population who were creating increasingly localised dynamics in the different territories. The landscape was crucial in creating bonds or imposing separations as a result of an adverse geography. The easiness of contact and the development of economic activities nurtured the establishment of links between families where peace and friendship took turns with moments of conflict and opposition. Afonso Mendes de Resende's journey in the sixteenth century is a case in point to understand the cultural, social, economic, and political organization in the frontier region; it also testifies to the daily contact around a borderline that is always present in both memory and demarcation of the territory.

Keywords: Frontier; Daily Life; Landscape; Economy; Society.
\end{abstract}


Resumo: As fronteiras que dividem os reinos peninsulares na Idade Média determinaram-se como resultado da Reconquista, da vontade política e do estabelecimento de povoadores que, nos diferentes territórios foram criando dinâmicas mais localizadas. A paisagem foi determinante na criação de vínculos territoriais ou de separações impostas por locais de uma geografia adversa. Em relação com as facilidades ou dificuldades de contacto e com o desenvolvimento das atividades económicas, as comunidades locais foram criando relações familiares, de paz e de amizade, que alternavam com momentos de conflito e com resistências. No século XVI, a viagem de Afonso Mendes de Resende e de Duarte de Armas permitem-nos entender a organização cultural, social, económica e política do espaço de fronteira e das relações quotidianas estabelecidas em torno dessa linha, sempre presente na memória e nas demarcações do território.

Palavras- chave: Fronteira; Vida quotidiana; Paisagem; Economia; Sociedade.

Sumario: 0. Introducción. 1. Paisajes y vivencias de la frontera de Alcoutim a Mértola: cuestiones sobre el Algarve. 2. Tierras ásperas: Mértola y Serpa. 3.- Moura, Noudar, Barrancos y Mourão: la tierra en disputa y las cuestiones en torno a los pastos. 4. Tierras de paz: Terenal y Alandroal. 5. De Olivença a Arronches: la disputa con Badajoz y Alburquerque. 6.- Tierras de relaciones menos difíciles: de Alegrete al Tajo. 7. Conclusión.

Summary: 0. Introduction. 1. Frontier landscape and daily life from Alcoutim to Mértola: 'Questions' on the Algarve. 2. Rough lands: Mértola and Serpa. 3. Moura, Noudar, Barrancos and Mourão: A land of contention and the issue of pastures. 4. Lands of peace: Terena and Alandroal. 5. From Olivença to Arronches: Dispute with Badajoz and Albuquerque. 6. Lands where easier relationships prevail: From Alegrete to Tejo. 7. Conclusions.

Sumário: 0. Introdução. 1.Paisagens e vivências da fronteira de Alcoutim a Mértola: "questões" no Algarve. 2. Terras ásperas: Mértola e Serpa. 3. Moura, Noudar, Barrancos e Mourão: a terra de contenda e as questões em torno dos pastos 4. Terras de paz: Terena e Alandroal 5. Olivença a Arronches: a contenda com Badajoz e Albuquerque 6. Terras de relacionamentos menos difíceis: de Alegrete ao Tejo. 7. Conclusão.

\section{INTRODUÇÃO}

A(s) fronteira(s) que limitam Portugal dos reinos vizinhos de Leão e Castela foram-se delineando ao sabor das conjunturas. As características das relações sociais, políticas, económicas e fiscais variavam de terra para terra ao longo destas linhas de separação, "mais ou menos" claras, que se foram desenhando desde os tempos da Reconquista ${ }^{1}$.

\footnotetext{
${ }^{1}$ Aceita-se como ponto de partida para o conceito de fronteira de Manuel González Jiménez. Para o autor fronteira é limes, marcas, franjas, mais ou menos permeáveis à entrada do Outro, marcações políticas do território com características, não apenas políticas, mas também culturais, linguísticas, religiosas, mentais. Caracteriza-as por fronteiras reais e imaginadas, individuais e de grupo, domésticas e públicas. Apesar de se referir com particular relevo à fronteira do Islão, o conceito adapta-se a outros territórios. González Jiménez, «Relación final», p. 293. Sobre a temática ver em particular Andrade, «A
} 
Para a sua análise parte-se de dois princípios base: como qualquer lugar delimitado pela ação político-militar, é um lugar de conflito, de invasão e de intromissão; como lugar habitado por uma sociedade que vive e se organiza em torno de um território, a familiaridade, a amizade e todas as ações e situações daí decorrentes, são naturais, ocasionais ou sistemáticas. A geografia vai desenvolvendo atividades económicas diferenciadas, organizando o povoamento e diversificando as relações humanas. Respondendo à questão "fronteira" ou "fronteiras", dir-se-ia: uma fronteira política, diversas fronteiras sociais e culturais, mas em particular um espaço de sociedades fronteiriças ${ }^{2}$, lugares onde vivem e convivem comunidades, estruturas medievais comparáveis a outras estruturas sociais territoriais. Não se pretende desenvolver neste estudo a conceptualização de "fronteira", nem se pretende desenvolver o debate em torno da fronteira enquanto elemento político, económico, religioso ou social construtor de espaços políticos mais ou menos demarcados e circunscritos. Pretende-se rever a paisagem, natural e cultural que, independentemente da ligação política mais ou menos central, vivem um dia-a-dia que as fontes aqui em estudo nos proporcionam espreitar. O estudo entrará mais numa perspetiva de terra fronteiriça alargada e menos na perspetiva de conceptualização da fronteira e do debate ideológico sobre a mesma ${ }^{3}$.

Naturalmente, como espaço privilegiado de conflito, a animosidade entre reinos ou entre senhores que procuram o saque ou a demonstração de poder impõe o redobrar da atenção sobre áreas menos defendidas. As relações entre vizinhos traduzem-se inúmeras vezes em atos de vandalismo, organizados por conta e risco próprios, que derivam de outras discórdias cuja origem não se determina bem por qual dos lados se iniciara. Como espaço de sociabilidade, vive entre a animosidade e a amizade estende-se na horizontalidade. Reforça-se o caminho traçado por Robert Bartlett e Angus Mackay ${ }^{4}$ e continuado por David Abulafia e Nora Berend ${ }^{5}$. As fronteiras não são apenas demarcações lineares, mas sim lugares de estabelecimento de comunidades que criam áreas de convívio, mais ou menos alargadas. Nestes lugares criam-se redes de relações humanas e redes de relação com a natureza que as envolve e direciona e condiciona.

A caracterização da fronteira entre Portugal e Castela por Armindo de Sousa é inspiradora para esta lição. Refere o historiador que "as gentes de fronteira vivem o seu quotidiano de invadir limites - geográficos, linguísticos, fiscais e políticos (ou

construção medieval do território». A título de exemplo que pode evidenciar os muitos discursos em torno da fronteira e as inúmeras hipóteses de citação, cita-se numa perspetiva europeia Murray, The North-Eastern Frontiers ou os inúmeros estudos desenvolvidos no âmbito do projeto liderado pela Universidade de Leeds e intitulado "Rethinking the Medieval Frontier : New Theories for Frontier Studies".

${ }^{2}$ Bartlett; MacKay, Medieval Frontiers Societies.

${ }^{3}$ Entre vários autores que seguem este modelo, anota-se O’Keeffe, «Frontiers of the Archaeological Imagination».

${ }^{4}$ Ibid.

${ }^{5}$ Abulafia; Berend, Medieval Frontiers. 
de obediência). Vive-se "numa espécie de território onde, de cá para lá e vice-versa, mais do que opções e rivalidades predominam as cumplicidades" ${ }^{\text {"6 }}$. Esse território de vivências "de cá para lá", suscita a curiosidade e as questões surgem. Por onde passava a fronteira? Como se vivia e convivia em terras nas quais as gentes, de facto ou aparentemente, se separavam? Quais os cenários paisagísticos e sociais que acompanhavam o quotidiano de uma linha de delimitação de reinos?

Na busca de fontes que responda às questões colocadas - que paisagens e que vivências - destacaram-se duas fontes essenciais: as Demarcações da Fronteira, datadas de $1538^{7}$ e o Livro das Fortalezas de Duarte de Armas realizado no reinado de D. Manuel no início do século XVI ${ }^{8}$. Estas fontes revelam o quotidiano de uma fronteira onde o conflito surge claramente no dia-a-dia.

Estes livros têm, em conjunto, uma leitura que revela objetivos concretos do poder central na observação e monitorização de uma área frágil e de perturbação. Refletem uma preocupação pela delimitação da fronteira e pela manutenção das suas marcas de identidade, pela vigilância sobre as demarcações dos limites das terras e das atividades económicas desenvolvidas local e regionalmente. Apenas cerca de trinta anos separam os dois livros, o que permitirá afirmar que o texto escrito por Mendo Afonso de Resende ${ }^{9}$ se aproxima no tempo dos desenhos de Duarte de Armas. As descrições completam-se e permitem identificar os locais de fronteira no início do século XVI.

O grande interesse destas fontes é despoletado pela objetividade e rigor de descrição do espaço a que os seus autores se encontram obrigados por determinação régia. Note-se que na Idade Média, o espaço geográfico descrito é frequentemente imaginado, irreal, realizado por alguém que desconhece pessoalmente o que descreve pois não o presenciou. Este facto tem sido inúmeras vezes referido pelos mais diversos autores que estudam cartografia ou que interpretam a paisagem histórica através de fontes. Esta descrição vaga e imprecisa é muitas vezes "usada" estrategicamente pelo poder político ${ }^{10}$. Mendo Afonso de Resende e Duarte de Armas partem para a descrição da fronteira através da visualização pessoal, salvo raras exceções. Questiona-se, como parece evidente, a total objetividade estando a serviço de um dos lados políticos. Não haverá, certamente, objetividade absoluta nas descrições. No entanto, reforce-se é uma passagem real pelos lugares. O valor histórico desta mensagem é, por este facto, significativo.

Duarte de Armas e o seu escudeiro fazem a viagem ao longo da raia a partir de Castro Marim até Caminha. Toda a fronteira é palmilhada e as fortalezas descritas com pormenor, de forma a proceder à sua manutenção ou reforma. Várias

\footnotetext{
${ }^{6}$ Sousa «Fronteira e representação», p. 54.

${ }^{7}$ Demarcações de Fronteira: De Castro Marim.

${ }^{8}$ Em 1509-1510. Duarte de Armas, Livro das fortalezas de Duarte de Armas.

${ }^{9}$ Portador das credenciais de D. João III que o habilitam para visitação, as fontes nada mais esclarecem quanto à sua identificação.

${ }^{10}$ Tamm, «A new world into words».
} 
informações podem ser recuperadas e a fronteira pode ser compreendida. Apesar das limitações do desenho de Duarte de Armas, estes são de relevo para a visualização do local nos seus elementos chave.

Mendo Afonso de Resende percorre a mesma paisagem e relata com grande pormenor por onde passa a linha fronteiriça, bem visível para os que a temem e a conhecem. Histórias e conhecimentos que passam de geração em geração e que constroem a memória e materializam a posse. Assim o revelam as palavras dos inquiridos. A ação de Mendo Afonso de Resende é ritualizada. Ao chegar a uma vila, reúne com os oficiais locais e questiona-os sobre a existência de documentos nas arcas do concelho. Nada fica por ver nas arcas concelhias, nenhum marco fica por visitar, nada fica por esclarecer nesta viagem que se inicia a 14 de julho de 1537 em Castro Marim e termina a 31 de julho de 1538 em Valença. Um ano intenso com paragens apenas para pernoita, algumas delas ao ar livre, por serem os viajantes apanhados pelo cair da noite ${ }^{11}$.

Indiscutivelmente importante é o registo escrito que Mendo Afonso de Resende sempre procurava nas arcas dos concelhos, ao lado da memória de homens mais velhos, que mantêm viva a história oral contada de geração em geração. As arcas concelhias guardam forais, livros de vereação, privilégios, cartas régias, inquirições e delimitações mais antigas, sentenças, documentos emanados da administração local e regional, assentamentos e compromissos de vizinhança, entre outros que garantem a continuidade do bem-estar relacional ${ }^{12}$.

Nos livros de demarcações, a área raiana desde a foz do Guadiana até ao Tejo regista zonas férteis, de atividades diversificadas que exploram os rios e as terras, onde a agricultura coabita com a criação de gado, e zonas áridas, mais abertas e menos férteis, mais propícias à passagem de gado nas suas deslocações em busca de prados. A aridez é entrecortada por cursos de água e charcos cobiçados como bebedouros pelos criadores de gado que por aqui circulam. As paisagens mais inóspitas, onde as fragas obrigam ao isolamento e à dificuldade de passagem, geram verdadeiras terras de ninguém, desabitadas e inalcançáveis. Os relatos são de uma paisagem mais selvagem que convive com outra mais humanizada pela presença de pastores e agricultores ${ }^{13}$.

Ao analisar a paisagem de Castro Marim até à confluência do Tejo, identificam-se claramente grandes áreas geográficas, políticas, económicas e sociais com entidades próprias. Identificam-se zonas de convívio mais fácil, mais organizadas nas suas relações, outras de convívio mais difícil onde as dúvidas e as incertezas deixam marcas de violência e de menor entendimento.

Uma vez que se pretende rever a fronteira tardo-medieval num determinado espaço, o estudo ficará pelo primeiro volume dos livros de Demarcações de

\footnotetext{
${ }^{11}$ Demarcações de Fronteira: De Castro Marim, p. 12. Esta cuidadosa demarcação foi já anotada por Andrade, «Entre Lima e Minho».

${ }^{12}$ Demarcações de Fronteira: De Castro Marim, p. 12.

${ }^{13}$ Freitas, «Caminhos que cruzam fronteiras», pp. 493-499.
} 
Fronteira. Nesta fronteira agrupam-se as paisagens em 6 grandes territórios unidos pelas mesmas características geográficas e de sociabilidade:

1. Castro Marim a Mértola: vivem em torno da proximidade do mar e da exploração que o rio proporciona;

2. Mértola e Serpa: terras isoladas pelas serranias;

3. Moura, Noudar, Barrancos e Mourão: zona de pastos e de passagens de gado;

4. Terena e Alandroal: terras onde se vive alguma paz e proximidade no convívio

5. Olivença a Arronches: área de conflito intenso

6. Vale do sul do Tejo: terras isoladas com vivências menos conflituosas.

Mapa 1. Terras de fronteira citadas nas fontes ${ }^{14}$

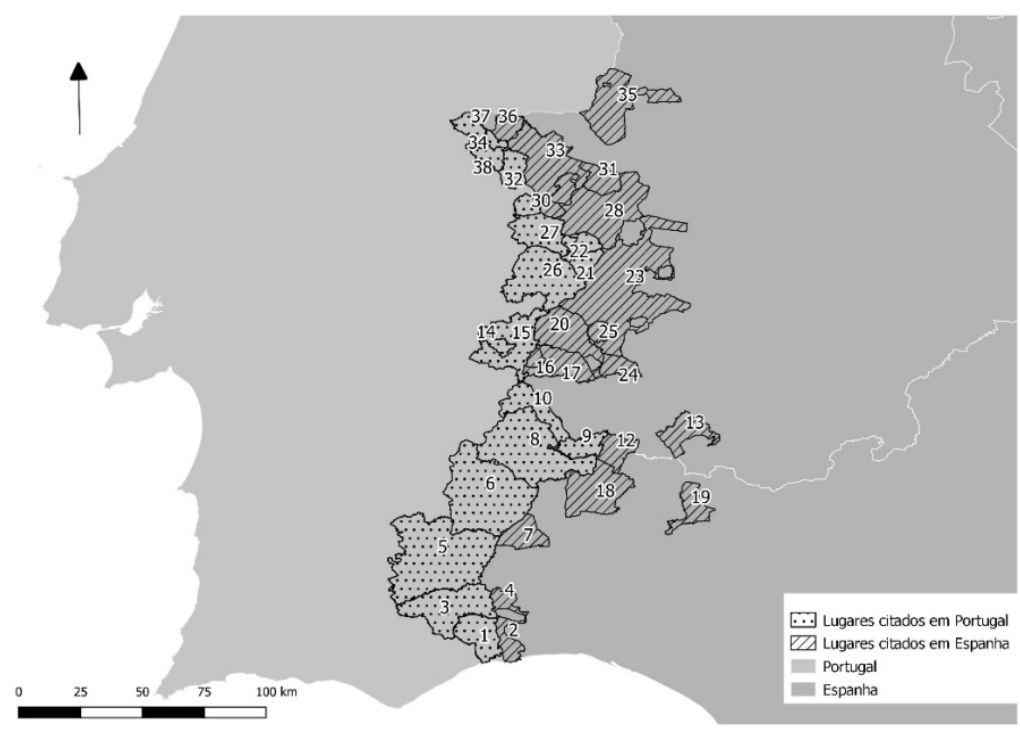

1 Castro Marim, 2 Aiamonte, 3 Alcoutim, 4 San Lúcar de Guadiana, 5 Mértola, 6 Serpa, 7 Paimogo, 8 Moura, 9 Noudar e Barrancos, 10 Mourão, 11 Aroche, 12 Ensinasola, 13 Fregenal, 14 Terena, 15 Alandroal, 16 Cheles, 17 Alconchel, 18 Aroche, 19 Aracena, 20 Olivença, 21 Campo Maior, 22 Ouguela, 23 Badajoz, 24 Barcarrota, 25 Valverde, 26 Elvas, 27 Arronches, 28 Albuquerque, 29 Alegrete, 30 La Codosera, 31 Maiorga, 32, Marvão, 33 Valência de Alcântara, 34 Meadas, 35 Alcântara, 36 Herrera. 37 Montalvão, 38 Castelo de Vide

\footnotetext{
${ }^{14}$ A autoria do Mapa 1 é de Helena Albuquerque, Professora Auxiliar da Universidade Portucalense e investigadora no REMIT (Research on Economics, Management and Information Technologies), centro de investigação da Universidade Portucalense.
} 


\section{Paisagens e VivênCias da fronteira de Castro Marim a Mértola: “QUESTÕES” NO ALGARVE}

A fronteira localizada entre Castro Marim e Mértola marca-se pela forte influência do Atlântico e da foz do Guadiana. Numa primeira linha de fronteira, junto à foz do Guadiana, a concentração demográfica em torno das atividades piscatória e mercantil permite individualizar toda a área diferenciando-a da que se encontra mais a norte.

Em Castro Marim a fronteira demarca-se pelo Guadiana, pelo fio do rio, segundo a inquirição realizada por Mendo Afonso de Resende. Na paisagem salienta-se o esteiro de Castro Marim ${ }^{15}$ e os dois sequeiros na boca do Guadiana. O primeiro sequeiro é um areal que fica descoberto na baixa-mar e onde pescam com chinchorros $^{16}$, junto do esteiro de Castro Marim, em frente à vila. $\mathrm{O}$ outro sequeiro está no meio do rio, ladeado por dois canais, um que entra em Portugal e outro que segue para Castela ${ }^{17}$. Da pesca salienta-se a sardinha, fumada e depois exportada por valentinos que a procuravam ${ }^{18}$.

A população, de ambos os lados da fronteira, vive da pesca e do trânsito comercial pela foz do Guadiana ${ }^{19}$. Em Castro Marim vive-se das conhecidas saboarias pretas e da construção naval ${ }^{20}$. $\mathrm{O}$ trânsito que circula pela rede de caminhos é coadjuvado na passagem do Guadiana pela barca que atravessa de Castro Marim para Aiamonte, explorada através de arrendamento, junto com a renda da portagem.

Como seria de prever, por terras de Castro Marim, os conflitos mais graves localizam-se em torno do rio Guadiana, fonte de exploração económica e piscatória $^{21}$. Por aqui fala-se de casas e igrejas queimadas durante a noite, barcos afundados por mandado do Duque e Senhor de Aiamonte ${ }^{22}$. Apesar deste clima de grande instabilidade, registam-se casamentos e ligações familiares entre as vilas de Aiamonte e Castro Marim ${ }^{23}$.

\footnotetext{
${ }^{15}$ Duarte, «Garcia de Melo», p. 132. Ver também Magalhães, «Algarve económico», p. 61.

${ }^{16}$ Chinchorro é uma técnica de pesca ainda hoje usada em muitos locais de águas baixas.

${ }^{17}$ Demarcações de Fronteira: De Castro Marim, p. 23.

${ }^{18}$ Carriazo Rubio, «Pesca, frontera y señorío», p. 47.

${ }^{19}$ Demarcações de Fronteira: De Castro Marim, p. 26.

${ }^{20}$ Duarte, «Garcia de Melo», p. 134.

${ }^{21}$ Para outras zonas da fronteira de grande vitalidade económica, nomeadamente zonas portuárias (portos secos) ver Freitas, Mercadores entre Portugal e Castela.

${ }^{22}$ Demarcações de Fronteira: De Castro Marim, p. 23.

${ }^{23}$ Ibid., p. 26. Carriazo Rubio anota o crescimento populacional de Aiamonte com base na atratividade de portugueses que construíam a sua vida em torno das atividades económicas aqui presentes. Em 1498 registavam-se 372 vizinhos em Aiamonte e em 1534 a vila registaria 1035 vizinhos. Carriazo Rubio, Juan Luis, «Pesca, frontera y señorío», p. 48.
} 


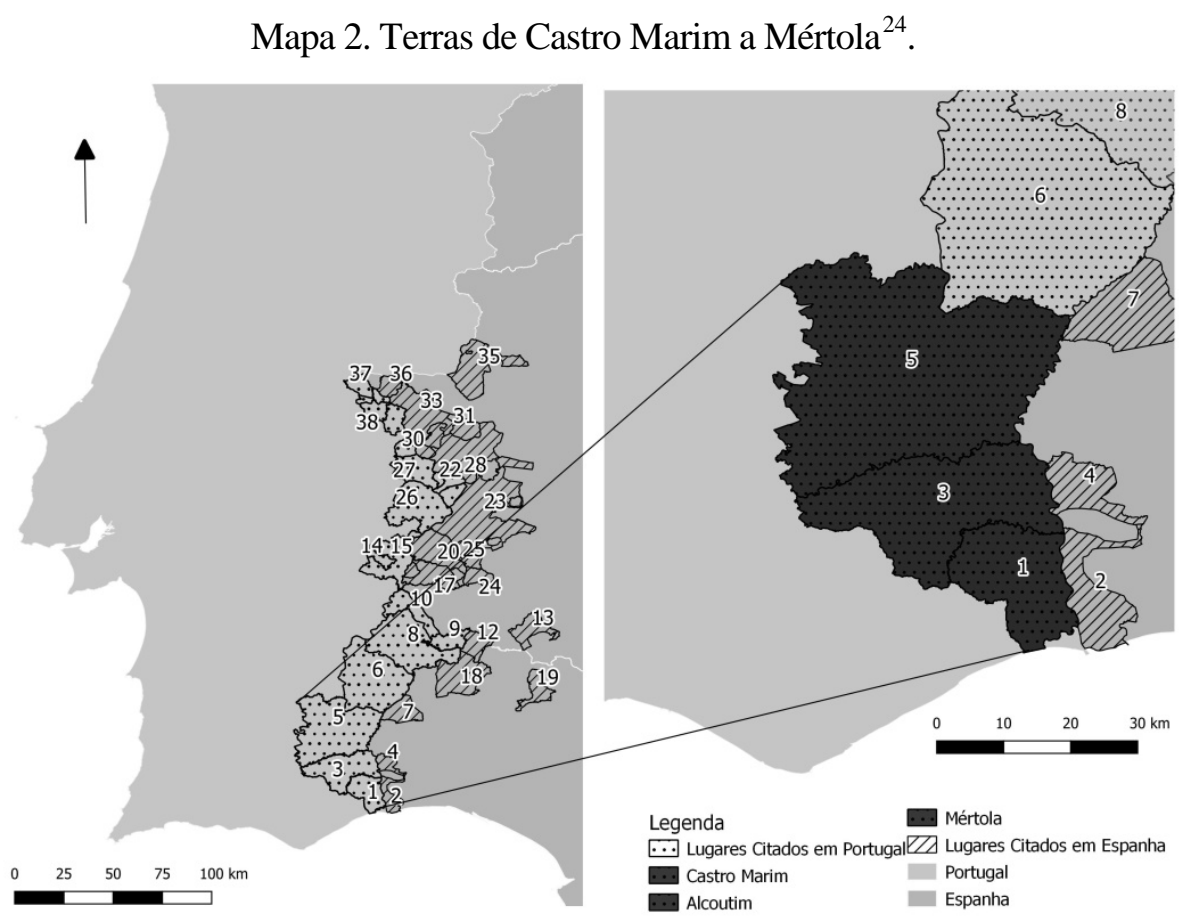

1 Castro Marim, 2 Aiamonte, 3 Alcoutim, 4 San Lúcar de Guadiana, 5 Mértola, 6 Serpa, 7 Paimogo, 8 Moura, 9 Noudar e Barrancos, 10 Mourão, 11 Aroche, 12 Ensinasola, 13 Fregenal, 14 Terena, 15 Alandroal, 16 Cheles, 17 Alconchel, 18 Aroche, 19 Aracena, 20 Olivença, 21 Campo Maior, 22 Ouguela, 23 Badajoz, 24 Barcarrota, 25 Valverde, 26 Elvas, 27 Arronches, 28 Albuquerque, 29 Alegrete, 30 La Codosera, 31 Maiorga, 32, Marvão, 33 Valência de Alcântara, 34 Meadas, 35 Alcântara, 36 Herrera. 37 Montalvão, 38 Castelo de Vide

Afirma-se que, em tempos passados, o Guadiana pertencia todo a Castro Marim até à margem de Aiamonte ${ }^{25}$, pelo que rendas e impostos só poderiam ser cobrados do lado português. Esclarecem os inquiridos chamados por Mendo Afonso de Resende que no final do século XV, em 1497, D. Pedro Stuñiga, senhor de Aiamonte [Pedro de Zuñiga y Manrique de Lara, I Conde de Ayamonte], obrigava os barcos a ancorarem em Aiamonte, contrariamente ao que acontecia até à data ${ }^{26}$. O sucessor de D. Pedro de Stuñiga, seu filho D. Francisco, continuou com a exigência de manter a linha de fronteira pelo meio do rio e os pagamentos de ancoragem a Aiamonte.

\footnotetext{
${ }^{24}$ A autoria do Mapa 2 é de Helena Albuquerque.

${ }^{25}$ Demarcações de Fronteira: De Castro Marim, p. 20.

${ }^{26}$ Pedro de Stuñiga era filho de Álvaro Stuñiga, duque de Arevalo que apoiou o partido de D. Joana e de Afonso $\mathrm{V}$ aquando da entrada deste em Castela. Pedro de Stuñiga, ao contrário de seu pai, apoiava Isabel, a Católica. Ver Moreno; Freitas, A corte de Afonso V.
} 
Os mesmos inquiridos explicam a mudança da localização da fronteira da margem de Aiamonte para o meio do rio e culpabilizam o alcaide de Castro Marim, Lopo Mendes de Oliveira, pela sua perda. Relata um dos inquiridos das demarcações que Martim Lopo Mendes era homem froxo e por sua froxesa deyxou emposear o Senhor de Aiamonte a metade do rio ${ }^{27}$. Percebe-se que os poderes locais agem por conta própria, indiferentes à política central, e percebe-se também a negligência na contenção dos desvios da fronteira e nas perdas de direitos.

Curiosamente, do lado de Aiamonte anotam-se as mesmas queixas. Carriazo Rubio revela um documento do Arquivo de Simancas, infelizmente sem data, no qual a população local afirma que do lado português se cobram direitos abusivos sobre as entradas dos barcos e a venda de produtos ${ }^{28}$.

De reter que pelos cursos de água que demarcam a fronteira, as delimitações podem estabelecer-se a meio do rio, ou pela margem contrária. De acordo com o estabelecido, os impostos e a exploração do rio fazem-se de forma diferenciada. Cabe ao poder local manter-se firme e agir em conformidade com as obrigações devidas ao seu rei. No entanto, a longa distância que separava a fronteira da corte permitia ações localizadas, pautadas pelo medir de forças constante.

Um documento datado de 1509, estudado por Luís Miguel Duarte, descreve algumas situações curiosas. Este documento, de "identidade problemática", conforme refere, cujo objetivo seria o de "convencer o rei", condena o alcaide de Castro Marim, Garcia de Melo, pela sua atuação nessas terras e regista que Garcia de Melo se apoderou dos direitos da alfândega e da renda da barca que cruzava o Guadiana para Aiamonte, entre outras. Subscrevemos a estranheza apontada por Luis Miguel Duarte em torno do tom desta carta muito pessoal dirigida a D. Manuel. Possivelmente o seu autor teria muito a agradar ao Senhor de Aiamonte. Para a população seria mais seguro um alcaide menos froxo, alguém como Garcia de Melo que tentava recuperar para Portugal um espaço perdido ${ }^{29}$.

O que salienta Duarte d'Armas? O castelo e a vila, a foz do Guadiana com entrada de barcos provenientes do Atlântico, o sequeiro em baixa-mar, os moinhos e as plantações fora de muralhas, algumas casas e uma igreja, provavelmente as vítimas dos ataques anos depois. Salienta ainda o esteiro, que parece ter uma importância fundamental na vida local.

\footnotetext{
${ }^{27}$ Demarcações de Fronteira: De Castro Marim, p. 27.

${ }^{28}$ Carriazo Rubio, «Pesca, frontera y señorío», p. 47.

${ }^{29}$ Duarte, Luís Miguel, «Garcia de Melo em Castro Marim», p. 131 e 141. Carriazo Rubio referindo-se às atividades comerciais da terra de Aiamonte revela que "los señores eran conscientes de esta realidade y lucharon por conservar los privilégios que disfrutaban o por adquirir otrosque no les correspondían, lo que daba lugar a pleitos, alteraciones e incluso actos de violência. Esto ocurrió frequentemente com las almandrabas en el litoral gaditano y onubense”. Na realidade as atividades comerciais que se estendiam pelo Atlântico transformavam estes portos em áreas fiscais cobiçadas e os conflitos acontecem naturalmente pela disputa do poder. Cariazo Rubio, Juan Luis, «Pesca, frontera y señorío», p. 46.
} 
Um pouco mais a norte, em Alcoutim, vizinho de Sanlúcar ${ }^{30}$, a proximidade não é das mais tranquilas. Continuam as questões de divisão do rio e das rendas dos barcos que cruzam o Guadiana na direção Mértola-Aiamonte.

Referem os inquiridos das demarcações que o rio pertence todo a Portugal até à margem de Sanlúcar ${ }^{31}$. Regista-se que Alcoutim é um porto aduaneiro de relevo no trânsito de mercadorias que seguem para Aiamonte e para Mértola. Como não poderia deixar de ser, pelo teor aduaneiro em terras portuguesas, as principais questões envolvem fuga aos direitos por parte de barcos castelhanos, comerciais ou de pesca. Na tentativa de fugir aos pagamentos, descarregavam-se as mercadorias para venda em terra, dispensando a comum venda no rio. Como até à margem o rio é da exploração da vila de Alcoutim, quem fizesse transações no rio estava sujeito a pagamentos $^{32}$.

A relação conflituosa entre Alcoutim e Sanlúcar foi estudada por Carriazo Rubio. O autor regista um episódio em 1487, ocorrido pela Páscoa, data em que muitos vizinhos de Alcoutim estavam em Sanlúcar para festejos. Note-se que a população circula pela fronteira e convive com amigos e parentes que se encontram do outro lado das linhas divisórias. Regista Carriazo Rubio um assalto dos vizinhos portugueses à vila de Sanlúcar ${ }^{33}$, para o qual usaram a caravela de D. Leonor da Silva $^{34}$. Ao alcançar a margem procederam ao assalto da vila, seguindo-se os habituais roubos em casas e barcos. Terminado o assalto, apura-se a responsabilidade que recai sobre $\mathrm{D}$. Leonor que, parece, instigou criados e acostados, em represália a um furto anterior escondido por Sanlúcar ${ }^{35}$. O documento demonstra as relações mais particulares de fronteira, onde os acontecimentos, mesmo festas, se podem transformar em grandes conflitos que envolvem toda a sociedade local. Inesperadamente, ou talvez não, as mulheres surgem a liderar estas retaliações e assaltos ao vizinho.

À data das inquirições de Mendo Afonso de Resende, os vizinhos de Alcoutim argumentam que os de Sanlúcar são amigos e bem querentes e parentes uns dos outros assumindo que muitos dos habitantes da vila são portugueses ${ }^{36}$. Uma paz conjuntural instalada? Retém-se que nas viagens de “cá para lá”, alguns vão ficando e adquirindo morada. Em Alcoutim não vivem só portugueses, em Sanlúcar não vivem só castelhanos. Revela-se que o conflito não é contra os castelhanos, mas contra os vizinhos de Sanlúcar.

\footnotetext{
${ }^{30}$ Hoje Sanlúcar de Guadiana.

${ }^{31}$ Demarcações de Fronteira: De Castro Marim, p. 36.

${ }^{32}$ Demarcações de Fronteira: Lugares de Trás-os-Montes. Ver ainda Freitas, Mercadores entre Portugal e Castela, p. 145 e Medrano, Un mercado entre fronteras.

${ }^{33}$ Carriazo Rubio, «Violencia y relaciones», p. 365-382.

${ }^{34}$ Refira-se que D. Leonor da Silva estava casada com D. Fernando de Meneses, Marquês de Vila Real, Senhor de Alcoutim e Governador de Ceuta.

${ }^{35}$ Carriazo Rubio, «Violencia y relaciones»

${ }^{36}$ Demarcações de Fronteira: De Castro Marim, p. 39.
} 
Uma terra bem movimentada, localizada na desembocadura do Guadiana, que lhe permitiu desenvolver ligações de curto, médio e longo curso, por terra e por mar. Assim a vê também Duarte d'Armas, que retrata a entrada de barcos vindos do Atlântico que sobem o Guadiana. A vizinhança muito próxima com Sanlúcar é de atestar pelas travessias por barcas.

\section{TERRAS ÁSPERAS: MÉRTOLA E SERPA}

Continuando para norte, as atividades comerciais marcam forte presença no dia-a-dia da população local. Ana Maria Pereira Ferreira identifica Mértola e Serpa como portos, entrepostos comerciais no interior ${ }^{37}$.

\section{Mapa 3. Terras de Mértola e Serpa ${ }^{38}$.}

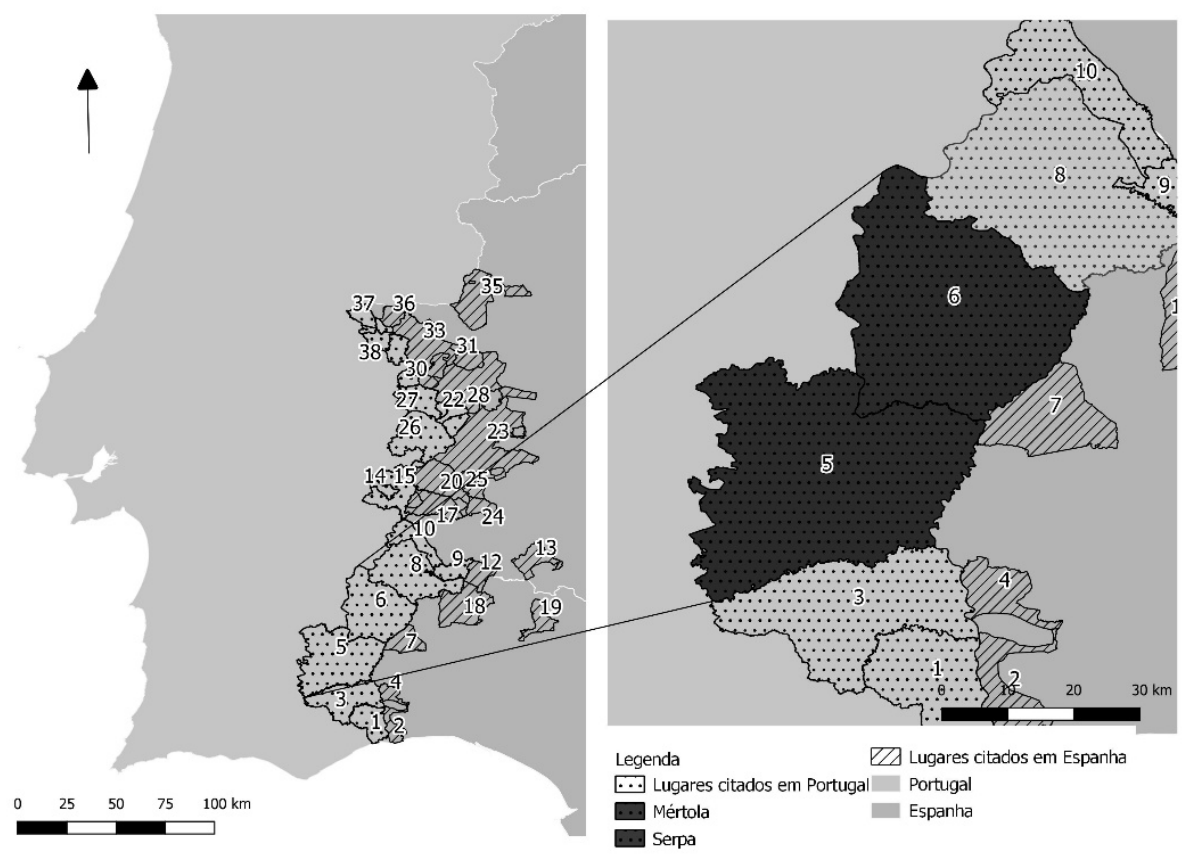

1 Castro Marim, 2 Aiamonte, 3 Alcoutim, 4 San Lúcar de Guadiana, 5 Mértola, 6 Serpa, 7 Paimogo, 8 Moura, 9 Noudar e Barrancos, 10 Mourão, 11 Aroche, 12 Ensinasola, 13 Fregenal, 14 Terena, 15 Alandroal, 16 Cheles, 17 Alconchel, 18 Aroche, 19 Aracena, 20 Olivença, 21 Campo Maior, 22 Ouguela, 23 Badajoz, 24 Barcarrota, 25 Valverde, 26 Elvas, 27 Arronches, 28 Albuquerque, 29 Alegrete, 30 La Codosera, 31 Maiorga, 32, Marvão, 33 Valência de Alcântara, 34 Meadas, 35 Alcântara, 36 Herrera. 37 Montalvão, 38 Castelo de Vide

\footnotetext{
${ }^{37}$ Ferreira, A importação.

${ }^{38}$ A autoria do Mapa 3 é de Helena Albuquerque.
} 
De Sanlúcar partem barcos para Aiamonte e para Mértola carregados de vinho e de mantimentos que pagam direitos em Portugal ${ }^{39}$. Refere Humberto Baquero Moreno que, em 1442, D. Pedro dava conta do comércio que entrava pelo Guadiana até ao porto de Mértola. Entre os vários produtos referem-se os lanifícios castelhanos que, ao contrário de todos os outros, não eram isentos do pagamento da dízima ${ }^{40}$. Por aí segue a via que liga Beja a Niebla ${ }^{41}$ e que completava todas as ligações comerciais por terra.

Por terras de Mértola há mudança na paisagem que, ao deixar o Guadiana, entra pela serra de Chança. Em terra firme, marcos e divisões permitem assinalar os limites entre ambos os reinos. Inicia-se uma área de terra rochosa, de acesso impossível em algumas zonas, por onde nem a pé nem a cavalo se passava ${ }^{42}$. Terra fragosa, árida, desprovida de valor agrícola e de pouco interesse para a pastagem de gado, que por isso não suscita conflitos. Sem disputa na posse, o acordo da demarcação encontra-se facilitado. Uma terra de ninguém por onde a fronteira passa mas não se sabe bem por que local.

Do lado da fronteira castelhana, o Duque de Medina Sidonia, senhor destas terras, parece não dedicar atenção aos movimentos dos portugueses, provavelmente porque atenderia mais às terras a sul, nomeadamente Sevilha e Sanlúcar de Barrameda, cidades bem mais apetecíveis que a frágil delimitação com Portugal. Por outro lado, Portugal fora lugar de refúgio para os Duques de Medina, o que permite a existência de boas relações fronteiriças ${ }^{43}$.

Duarte d'Armas regista a mudança de paisagem para uma área fragosa, a Ribeira de Oeiras e a sua navegabilidade (ausente dos livros de demarcações por não ser fronteira ${ }^{44}$ ), os pilares de uma ponte de construção muçulmana, uma mesquita transformada em igreja, um pano de muralha com área considerável, uma cisterna obstruída junto às muralhas ${ }^{45}$, e regista, no Guadiana, a subida de barcos de comércio provenientes do Atlântico.

Em Serpa, não existem dúvidas por onde passa a fronteira. O meio da Ribeira de Chança delimita Serpa de Paimogo, Niebla e Aroche ${ }^{46}$. Na ribeira, sempre que possível, existem moinhos e açudes que se encontram bem regulados por tradição e não se originam conflitos. Anota-se que a ribeira de Chança, larga e de caudal fixo, permite verificar claramente a fronteira entre os dois reinos.

Refere Santiago Macías que a fronteira do Chança parece segura, por constituir uma barreira geográfica de relevo, mas na realidade não o é. Por aqui

\footnotetext{
${ }^{39}$ Demarcações de Fronteira: De Castro Marim, p. 37.

${ }^{40}$ Moreno, «Relações marítimas», p. 11.

${ }^{41}$ Macías González, «El problema historiográfico», p. 996.

42 Demarcações de Fronteira: De Castro Marim, p. 44.

${ }^{43}$ Galán Parra, «El linaje y los estados señoriales», p. 45-78.

${ }^{44}$ É um afluente da margem direita do Guadiana que nasce na Serra do Caldeirão e desagua em Mértola.

${ }^{45}$ Freitas, «A água no Livro das Fortalezas», p. 163-177.

${ }^{46}$ Demarcações de Fronteira: De Castro Marim, p. 47.
} 
passavam vias importantes de ligação Beja/Sevilha e a via que ligava Évora a Sevilha e que fazia ligação com a Via da Prata ${ }^{47}$, logo locais de passagem, mas com inúmeras fragilidades provenientes do despovoamento e da aridez do território que estas vias cruzam. As Demarcações insistem que as serras envolventes de Serpa têm aspeto áspero e são despovoadas e, afirmam que nenhum homem pode andar pela margem do rio pelo vale áspero ${ }^{48}$. A passagem de vias com significado por este local isolado atraía de salteadores e a proximidade da passagem de viajantes e peregrinos desencadeava alguns episódios mais violentos. Os castelos terão aqui um papel fundamental.

Assim o mostra Duarte d'Armas: uma atalaia em local elevado, a vila velha e a vila nova, com o seu castelo, alguma ruína numa das torres da muralha e a proximidade de Beja. Note-se que as vias de cruzamento de mercadorias e de pessoas são alvos fáceis e apetecíveis.

Caminhando na direção de Rosal de La Frontera, na delimitação de Moura assinalam-se alguns conflitos. Entramos na Terra da Contenda.

\section{MOURA, Noudar, BARRANCOS E MOURÃO: A TERRA DE CONTENDA E AS QUESTÕES EM TORNO DOS PASTOS}

Essa conflitualidade encontrava-se bem assinalada pela presença de castelos, atalaias e torres que marcavam presença nos dois lados da fronteira. Santiago Macías ${ }^{49}$ lembra que desde o reinado de D. Dinis se sentia a necessidade de reforçar esta linha militar, que se inicia em terras de Moura e se prolonga por Noudar e Barrancos, facto que justifica as obras de reforço detetadas nestes castelos de defesa, em especial no de Noudar ${ }^{50}$.

Nas proximidades do castelo de Moura, entre outros sistemas defensivos, salienta-se Aroche, Encinasola e Fregenal. Numa segunda linha paralela mais afastada da fronteira os castelos de Torres ${ }^{51}$, Cortegana e Cumbres Maiores, e numa outra linha, ainda mais interior, Aracena, Cala e Santa Olalla ${ }^{52}$. A presença próxima destes castelos permite verificar que o conflito na fronteira com Portugal é uma realidade e que dominar as passagens da serra de Aroche seria uma prioridade. Outros sistemas defensivos mais localizados como as atalaias e torres (a título de exemplo, a Atalaia do Rolão, a Atalaia Magra, localizada no caminho que vai para Aroche $^{53}$ e a Torre Queimada ${ }^{54}$ ) são delimitadores da linha fronteiriça e reforçam as linhas de castelos criando uma verdadeira rede de comunicação, defesa e ataque.

\footnotetext{
${ }^{47}$ Macías González, «El problema historiográfico», p. 996.

${ }^{48}$ Demarcações de Fronteira: De Castro Marim, p. 48.

${ }^{49}$ Macias González, «Moura na Baixa Idade Média », p. 132.

${ }^{50}$ Macias González, «Moura na Baixa Idade Média », p. 134.

51 Jiménez, «Torres, un castillo onubense», p. 97-118.

${ }^{52}$ Prado Sagrera, «Dos castillos de tiempos de Sancho IV», p. 179, 180. Ver ainda Prado Sagrera, «El castillo de Cumbres Mayores», p. 473-500.

${ }^{53}$ Macias, «Moura na Baixa Idade Média», p. 144.
} 


\section{Mapa 4. Terras de Moura, Noudar e Barrancos ${ }^{55}$.}

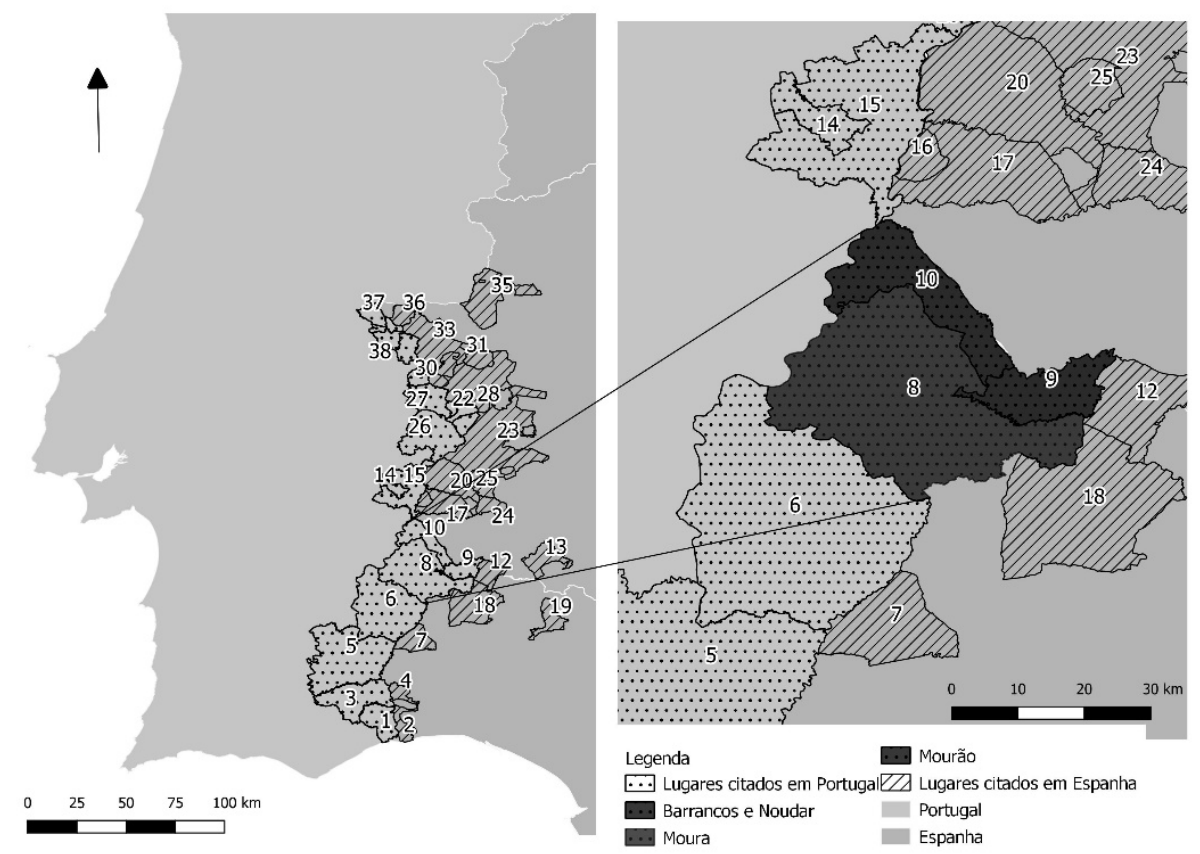

1 Castro Marim, 2 Aiamonte, 3 Alcoutim, 4 San Lúcar de Guadiana, 5 Mértola, 6 Serpa, 7 Paimogo, 8 Moura, 9 Noudar e Barrancos, 10 Mourão, 11 Aroche, 12 Ensinasola, 13 Fregenal, 14 Terena, 15 Alandroal, 16 Cheles, 17 Alconchel, 18 Aroche, 19 Aracena, 20 Olivença, 21 Campo Maior, 22 Ouguela, 23 Badajoz, 24 Barcarrota, 25 Valverde, 26 Elvas, 27 Arronches, 28 Albuquerque, 29 Alegrete, 30 La Codosera, 31 Maiorga, 32, Marvão, 33 Valência de Alcântara, 34 Meadas, 35 Alcântara, 36 Herrera. 37 Montalvão, 38 Castelo de Vide

A contenda em terras de Moura, Noudar, Barrancos e Mourão iniciou-se em meados do século XIII, data em que Antonia Carmona Ruiz regista os primeiros documentos relativos a estas questões. Reforça a autora que se acordara manter as fronteiras estabelecidas pela administração muçulmana; no entanto, esse acordo não se concretizou de forma pacífica ${ }^{56}$. Pelo apurado, a documentação castelhana delimita a terra da contenda pelos principais cursos de água. Partia da foz do Álamo, seguia até ao rio Chança em Aroche, passava pelo ribeiro de Murtigão e daí ia à Torre Queimada ${ }^{57}$.

\footnotetext{
${ }^{54}$ A referência a Torre Queimada data já de um documento de 1290, referido em Carmona Ruiz, M«La explotación ganadera de la frontera», p. 246.

55 A autoria do Mapa 4 é de Helena Albuquerque.

${ }^{56}$ García Fernández, «La Política Internacional de Portugal», p. 903-943.

${ }^{57}$ Carmona Ruiz, «La explotación ganadera de la frontera», p. 243-247.
} 
As demarcações de fronteira também delimitam a terra da contenda por termo de Moura, Aroche e Encinasola por espaço de duas léguas e meia a três léguas, e marcam o início das questões pelos anos 50 do século XIV. Relatam represálias sobre gados, homens presos e o encontro de negociadores portugueses e castelhanos, que se juntavam na tentativa de encontrar soluções para a paz. Entre os citados encontram-se os Licenciados Manuel Afonso, Pero de Resende, Fernão Rodrigues Pardal e Martim Rodrigues, Mateus Luís, tabelião em Évora, Fernão Mouzinho de Évora, juiz, Vasco Fernandes, Antão de Macedo, juiz de Moura, Pero Dias, André Serão e Afonso Peres Faria, corregedor, que representaram a parte portuguesa nas diversas reuniões. Quanto aos representantes por Castela referem-se as presenças de Rodrigo de Cala, Letrado Cabera, Diogo de Roges, Diogo Ordoñez $^{58}$. Contam os inquiridos que o processo não se concluiu por falta de acordo e de assentamento das partes de Castela.

Seguiram-se outras diligências da diplomacia portuguesa, mas mantinha-se a falta de acordo dos vizinhos castelhanos ${ }^{59}$. Ao olhar para o número de negociadores citados pela fonte e com as devidas reservas de ausência na memória dos inquiridos, será possível referir que o maior número de negociadores apresentados por Portugal apontaria para um maior interesse em resolver as questões conflituosas na fronteira. Essa opinião já foi referida por José Martín-Martín ${ }^{60}$.

Por terras de Moura atravessam-se pastos, terras de matos, azinhais e sobreiros que se associam a colmeais ${ }^{61}$. Cruzadas por diversos cursos de água, são excelentes pastagens. Salientam-se os rios Álamo, Chança, os ribeiros do Cortideiro, de Vale Queimado, de Gamos, de Murtigão, de Pai Joanes, de Safareja e dos Cavalos ${ }^{62}$. Note-se que a forte presença da água permitirá criar espaços extremamente atrativos para a passagem de rebanhos e de outros gados que procuram charcos, pastos e montados mais ricos, de tal forma que as semeaduras de pão são proibidas para não diminuir as pastagens ${ }^{63}$. Reserva-se este cultivo a Alpedra, argumentando que o baixo rendimento das restantes terras com cultivo de cereais não justificava o investimento e prejudicava a economia baseada na transumância ${ }^{64}$.

Enrique Rodríguez Picavea explica o desenvolvimento da transumância e da criação de gado em zonas de fronteira por três grandes motivos: os históricos, pela persistência desta atividade ao longo dos tempos em áreas pouco povoadas; os geográficos, ou seja, condições físicas propícias ao desenvolvimento de pastagens;

\footnotetext{
${ }^{58}$ Demarcações de Fronteira: De Castro Marim, p. 54-55.

${ }^{59}$ Ibid., p. 54 e 59.

${ }^{60}$ Martín-Martín, «Conflictos luso-castellanos».

${ }^{61}$ Demarcações de Fronteira: De Castro Marim, p. 59.

${ }^{62}$ Ibid., p. 52-53.

${ }^{63}$ Carmona Ruiz, «La explotación ganadera de la frontera», p. 250. Esta questão da proibição de semear cereais por estas terras está também claramente referida nos livros de demarcações de fronteira. Demarcações de Fronteira: De Castro Marim, p. 52.

${ }^{64}$ Rodriguez Picavea-Matilla, «La Ganadaría en la economía de frontera», p. 183.
} 
e os militares, pela adequação de uma atividade económica com carácter itinerante ${ }^{65}$.

Terra propícia ao estabelecimento de criadores de gado que, por norma, geram conflitos no uso e exploração dos territórios. Como refere José Luis Martín, os grupos de camponeses e de criadores de gado aproveitam áreas mais vulneráveis nas suas demarcações para, independentemente dos poderes locais ou centrais, avançarem sobre os territórios ${ }^{66}$. Embora o refira para o século XIII, estas situações continuaram a suceder nos séculos seguintes e parecem ser uma constante, direta ou indiretamente apoiadas pelo poder político local.

$\mathrm{O}$ crescimento refletido no século XV de uma forma geral para todas as cidades, também se verificou nas áreas de fronteira. Antonia Carmona salienta que entre os anos de 1407 e 1486, em Encinasola, assiste-se a um crescimento de 34 vizinhos para 190. Assinala, como consequência, o crescimento da exploração ganadeira que trazia muitos pastores a toda esta área ${ }^{67}$ e obrigava ao alargamento de pastos, o que terá produzido algumas questões mais graves. Mercedes Borrero assinala a partir desta data, fins do século XV, um decréscimo acentuado da população que culmina em 1534, período em que se regista uma crise económica agrícola local $^{68}$.

O crescimento da atividade resultante da criação de gado e de rebanhos, detetado no século XV, causa também discórdias em Portugal. Humberto Baquero Moreno revela uma carta de 1459 que refere que pelos portos de Noudar e Mourão entra gado em grande número. Queixam-se os concelhos do Alentejo nas cortes de 1481-82 que pelos portos do Guadiana entravam 50 ou 60 mil ovelhas que danificavam os pastos portugueses ${ }^{69}$. Salientam que Noudar seria um ponto de passagem de gados vindos de Castela, que tomavam, depois de entrar em Portugal, o caminho de Moura em direção aos campos de Ourique ${ }^{70}$.

Rosal, Campo de Gamos, Serra de Picos de Aroche, Poços de Aroche, Cervas, Val Queimado, são estruturas geográficas localizadas por todo o território e que se repetem na documentação como terras de acontecimentos agressivos. Nestes locais, a fronteira cruza, por terra, pontos demarcados por marcos, que nem sempre deixam claro a passagem da linha raiana. Em locais de dúvida ou indefinição, logo se registam narrativas de violações. Confirma-o Manuel González Jiménez ${ }^{71}$ que

\footnotetext{
${ }^{65}$ Ibid., p. 183.

${ }^{66}$ Martín Martín, «La tierra de las “contiendas”», p. 279.

${ }^{67}$ Carmona Ruiz, «La explotación ganadera de la frontera», p. 249.

${ }^{68}$ Borrero Fernández, «Los lugares de Fregenal», p. 22.

${ }^{69}$ Moreno, «Relações marítimas e comerciais», p. 12.

${ }^{70}$ Moreno, «Relações marítimas e comerciais». Macias González, «El problema historiográfico», p. 995. Amândio Barros regista o uso dos pastos e as passagens neste percurso, entre Noudar e Aroche, desde finais do século XIII (ano de 1290) e assinala o consequente desvio de marcos provenientes da passagem e das necessidades de aumento de terras para pastagens. Barros, «Uma contenda», p. 325

${ }^{71}$ González Jiménez, «Conflictos fronterizos», p. 195.
} 
assinalou que, desde o Rosal até ao Rio Ardila, as delimitações em terra deixavam alguns lugares indefinidos, o que provocava mal-estar.

As histórias em torno do derrube e desvio de marcos, como o que esconderam num ribeiro, de onde foi resgatado, ou o marco de ferro violentamente arrancado do penedo onde se encontrava, denotam a tensa vizinhança que por aqui se vivera e vivia à data das demarcações de Mendo Afonso de Resende. Na documentação portuguesa as acusações de desvios, roubos ou danos em marcos feitos por castelhanos são uma constante e nas fontes castelhanas as mesmas acusações são feitas a portugueses.

As diversas referências a caminhos que cruzam estas terras testemunham ligações comerciais e relações sociais mais tranquilas. De Moura para Aroche segue um caminho, de Santo Aleixo para Aroche segue outro ${ }^{72}$. Santiago Macías refere as ligações a Aroche, Serpa, Beja, Évora e Mourão ${ }^{73}$. Em terras de Moura e Mourão, há, ainda, referências a outros caminhos que fazem a ligação a Valência. Não há dúvida de que a circulação de pessoas e bens é uma constante.

Em Moura, Duarte d'Armas salienta o castelo com alguma dimensão, o casario que se estende para leste, naturalmente salvaguardado pelos postos avançados de Noudar e Barrancos.

Ao entrar no território de Noudar e Barrancos, vizinha com Encinasola, continuamos em terras de pasto, povoadas por cegonhas e lobos, por onde crescem figueiras e azambujeiras. As antas, moinhos, fornos e ermidas marcam a fronteira ao lado de cursos de água que fertilizam a terra. A Ribeira de Ardila, Ribeiro das Taipas, Ribeiro de Galiana, Ribeira de Múrtega, e o Guadiana, ao lado muitos outros ribeiros referenciados na fonte, mantêm os pastos ativos. Referenciam-se fragas e penedias, ladeadas por outeiros.

Duarte d'Armas desenha-nos esta paisagem onde fragas e outeiros coexistem. Salienta a Ribeira de Múrtega e a Ribeira de Ardila, que serão fundamentais na divisão dos termos com Castela. Referem os inquiridos de Mendo Afonso que por onde a fronteira se demarca pelas ribeiras de Múrtega e Ardila, os termos estão bem definidos quer por marcos quer pelo curso da água ${ }^{74}$.

Apesar de bem delimitada, há indefinições na passagem da fronteira. Relata Antónia Carmona que em $1491^{75}$, data de reabertura do processo de confronto de Noudar com Encinasola, discutiam a exploração da Defesa de Múrtega, quando o alcaide de Noudar, Gomes da Silva, apresou os gados do concelho de Encinasola ${ }^{76}$.

Manuel González Jiménez identificou a área de Barrancos, integrante da Contenda, como um local chave do conflito que autonomizou, designando por

\footnotetext{
${ }^{72}$ Demarcações de Fronteira: De Castro Marim, p. 53.

${ }^{73}$ Macias González, «Moura na Baixa Idade Média», p. 144.

${ }^{74}$ Demarcação feita por Martim Piteira Pardo e o mestre de Encinasola mantinha a terra afastada da contenda. Demarcações de Fronteira: De Castro Marim, p. 65, 66.

${ }^{75}$ Carmona Ruiz, «La explotación ganadera de la frontera», p. 255-256.

${ }^{76}$ Ibid., p. 250.
} 
"Pleito de Barrancos", e localizou nas terras designadas de Rincón de Juan Martins ${ }^{77}$. Assinala que Barrancos é uma povoação colonizada por muitos castelhanos provenientes da pressão demográfica crescente na Serra de Aroche, em particular de Fregenal, Aroche e Cumbres, acompanhada pela política de atração de moradores por parte da Comenda de Noudar, de quem dependia Barrancos. Mercedes Borrero acrescenta que as terras vizinhas portuguesas são um atrativo para os povoadores de Encinasola e de Aroche nos séculos XV e XVI, apesar da vivência difícil, registando alto índice de emigração na área ${ }^{78}$.

Com base num documento de 1493, Manuel González Jiménez descreve a ação de Vasco Fernandes, juiz português que se encontrou com o juiz castelhano Rodrigo de Coalla ${ }^{79}$. Ambos dialogaram sobre o conflito, tentaram encontrar soluções (pelo menos a parte portuguesa tentou) em vão. $\mathrm{O}$ documento de Rodrigo de Coalla ou Cala não é conhecido, o documento redigido por Vasco Fernandes encontra-se nas Gavetas da Torre do Tombo ${ }^{80}$. A presença de Rodrigo de Coalla teria sido insultuosa e injuriosa, maltratando os moradores castelhanos de Barrancos, chamando-lhes portugueses putos, maos, tredores, enalheadores da terra. O alcaide era um personagem bem conhecido na região pela uso de linguagem pouco digna e pela frequência de locais usuais de prostituição da vila de Fregenal $^{81}$. Ser chamado de português era considerado um insulto.

Dado interessante introduzem os inquiridos de Mendo Afonso de Resende informando que, na altura da referida visita destes representantes, o conflito não ficou sanado porque o juiz castelhano não o quis solucionar. Provavelmente o documento que este deveria redigir não surge atualmente no Arquivo em Sevilha porque o juiz nunca o escreveu. Parece claro que este se opôs à conclusão das desavenças, o que terá levado a Câmara da vila de Moura a anotar o facto, conforme refere, para seu resguardo ${ }^{82}$.

Os inquiridos afirmam que, após esta visita, vistoriaram o local Martim Rodrigues, juiz da vila de Moura com o Letrado chamado de Cabreira e, mais uma vez, o juiz castelhano não quis assentar nada ${ }^{83}$, mantendo-se a necessidade de impor a paz no local da contenda e terra de referta e a urgência em terminar com as represálias locais ${ }^{84}$.

\footnotetext{
${ }^{77}$ González Jiménez, «Conflictos fronterizos», p. 195.

${ }^{78}$ Borrero Fernández, «Situación demográfica», p. 62.

${ }^{79}$ Citados na demarcação de Moura, o juiz castelhano citado como Rodrigo de Cala, Demarcações de Fronteira: De Castro Marim, p. 54.

${ }^{80}$ González Jiménez, «Conflictos fronterizos», p. 195.

${ }^{81}$ Ibid., p. 198.

${ }^{82}$ Conforme dito anteriormente, González Jiménez refere que este documento não se encontrou em arquivo. González Jiménez, «Conflictos fronterizos», p. 198.

${ }^{83}$ Martin Martin, «Conflictos luso-castellanos», p. 260 e 261. Demarcações de Fronteira: De Castro Marim, p. 54. Ora, a descrição da ausência de registo castelhano nas delimitações está comprovada na fonte estudada. Demarcações de Fronteira: De Castro Marim, p. 55.

${ }^{84}$ Demarcações de Fronteira: De Castro Marim, p. 54-55.
} 
A não solução das questões, que prejudicavam as relações entre vizinhos portugueses e castelhanos, implicou uma nova represália por parte da população da vila de Moura a terras de Castela. Esta invasão de terras castelhanas parece ter funcionado, referindo-se que os castelhanos entom tomaram algum assento ${ }^{85}$. É de admitir que a falta de registo escrito castelhano fosse estratégica procurando evitar 0 acordo e o vínculo a acordos.

Antonia Carmona assinala que em 1503 se arrolou uma outra visita de Simão Correia como representante da parte de Portugal e Alonso de Sarabia por parte de Sevilha. Tentavam repor os ânimos após a entrada da população de Moura em Terras de Aroche, com a consequente destruição de colmeias, linhares e vinhas. Uma vez mais, não se conhece a resolução nem o registo de acordo ${ }^{86}$.

O pleito parece ter acalmado graças à concórdia estabelecida pela vinda de novos representantes: o castelhano D. Diogo Ordoñez, vindo de Sevilha e o português Afonso Peres. Acordou-se a delimitação da área da foz do rio Álemo até à Defesa das Cervas. Em 1537, a questão de Noudar e Barrancos parece estar solucionada. A paz mantém-se em 1541, aquando da concretização do assento de colmeia e de um acordo sobre a terra da contenda que regula a atividade pastoril e o cultivo agrícola e protege a terra de pasto e de matos ${ }^{87}$. Saliente-se a referência a assentamentos sobre as explorações acordados entre vizinhos que, pela designação, obrigariam certamente a um documento escrito. Assim, depois do conflito, seguirse-ia o assentamento que regulava a paz, pelo menos durante algum tempo. Responde-se parcialmente à questão anteriormente levantada pela observação de Armindo de Sousa relativa à parca existência de capítulos de cortes que registem problemas de fronteira com maior intensidade, apesar de a presença em cortes dos procuradores de concelhos fronteiriços ser até excessiva ${ }^{88}$. As ofensas em terras de fronteira seriam, provavelmente na sua maioria, solucionadas com acordos e assentamentos locais que obrigavam à deslocação de oficiais para verificação das demarcações e para a efetuação de inquirições que suportassem as soluções e acordos.

Continuando o percurso de Mendo Afonso de Resende, segue-se o castelo de Mourão, localizado um pouco mais a norte na área da contenda. A vila faz fronteira com Valência e Villa Nueva del Fresno, por terra, e pelas ribeiras de Ardila, ribeiros das Taipas, Galiana, Zaos, Godelim, entre outros.

A informação sobre desavenças mencionam situações idênticas às anteriores e as questões continuam a centrar-se em torno dos pastos e das campinas com azinheiras, do derrube de marcos, para obtenção de mais terras para cultivo de

\footnotetext{
${ }^{85}$ Ibid., p. 55.

${ }^{86}$ Carmona Ruiz, «La explotación ganadera», p. 253.

${ }^{87}$ Ibid., p. 255-256.

${ }^{88}$ Armindo de Sousa refere uma participação de 35 concelhos de fronteira num total de 80 concelhos presentes em cortes e apenas $2,8 \%$ de temas relacionados com questões de fronteira. Sousa, «Fronteira e representação parlamentar», p. 58 e 60.
} 
cereais, das mortes de civis ou de vigilantes das delimitações de fronteira ${ }^{89}$. Por aqui a população está sempre preparada, com seus cavalos e armas, para se defender dos castelhanos que a todo o momento poderiam cruzar o Guadiana ${ }^{90}$.

Também em Mourão se registam encontros de representantes portugueses e castelhanos para solução de conflitos e fala-se de documentos religiosamente guardados nos arquivos do concelho português. É o caso do documento de 1436, pelo qual sabemos que Diogo Gil Ferreira, ouvidor de D. Duarte e Vasco Domingues, corregedor entre Tejo e Guadiana pelo lado português e, pelo lado de Castela, João Rodrigues, assinaram um acordo sobre o termo de Valença e de Mourão ${ }^{91}$. De assinalar a visível proximidade dos castelos que permite concluir sobre a forte vigilância portuguesa e castelhana em toda esta área, reforçando uma sociabilidade que impunha o resguardo e a intervenção militar defensiva/ofensiva.

\section{TERRAS DE PAZ: TERENA E ALANDROAL}

Mais a norte, Terena e Alandroal partem com Cheles, Alconchel e Villanueva del Fresno. Um ribeiro divide os dois reinos e pelo Guadiana a fronteira passa pelo fio e o meio da água. Em Terena e Alandroal, área mais pacífica na zona de fronteira, a população convive melhor com os vizinhos de Cheles, Alconchel e Villanueva del Fresno $^{92}$. Os inquiridos dizem desconhecer contendas na demarcação destas terras. Os moinhos com os seus açudes que alcançam o meio do rio Guadiana, exploram-se de comum acordo, sem registo de problemas ${ }^{93}$. A paz que por aqui se vive deveria relacionar-se com a presença de Olivença, que funcionaria como posto avançado, por esta região, e atuava na proteção das vilas mais próximas e colocadas na sua retaguarda.

A barca que faz a passagem entre Terena e Cheles pertence ao Senhor de Cheles e ao Rei de Portugal. Explora-a um barqueiro morador em Cheles, Simão Freire, que mantém o arrendamento feito aos seus ascendentes familiares. A passagem da renda para Simão Freire não se encontra bem documentada e deixa algumas dúvidas aos inquiridos, conforme o expressam, mas não causa qualquer conflito no local. Aceita-se a prática que vem já de algumas gerações ${ }^{94}$.

Duarte d'Armas permite-nos visualizar um castelo de pequenas dimensões e reforça a presença de Santa Maria de Terena $^{95}$, igreja com características defensivas.

\footnotetext{
${ }^{89}$ Barros, «Uma contenda», p. 326.

${ }^{90}$ Ventura, «Os coutos de homiziados», p. 607.

${ }^{91}$ Demarcações de Fronteira: De Castro Marim, p. 58.

92 Ibid., p. 81.

${ }^{93}$ Ibid., p. 82-83.

${ }^{94}$ Demarcações de Fronteira: De Castro Marim, p. 83.

${ }^{95}$ Hoje Nossa Senhora da Boa Nova de Terena, registe-se que se mantém inalterável na sua estrutura arquitetónica desde o século XIV.
} 
No Alandroal, fronteira com Cheles e Alconchel, a fronteira passa de igual forma pelo fio e meio do rio Guadiana. Nas ribeiras, os moinhos exploram o rio, acordando o local por onde se estabelecem os açudes. Duarte d'Armas registou em desenho a lagoa que permite uma excelente irrigação das terras cultivadas envolventes ao castelo no seu lado sul. Atesta-se a importância da água como elemento defensivo e como elemento essencial à vida do homem.

\section{Mapa 5. Terena e alandroal ${ }^{96}$.}

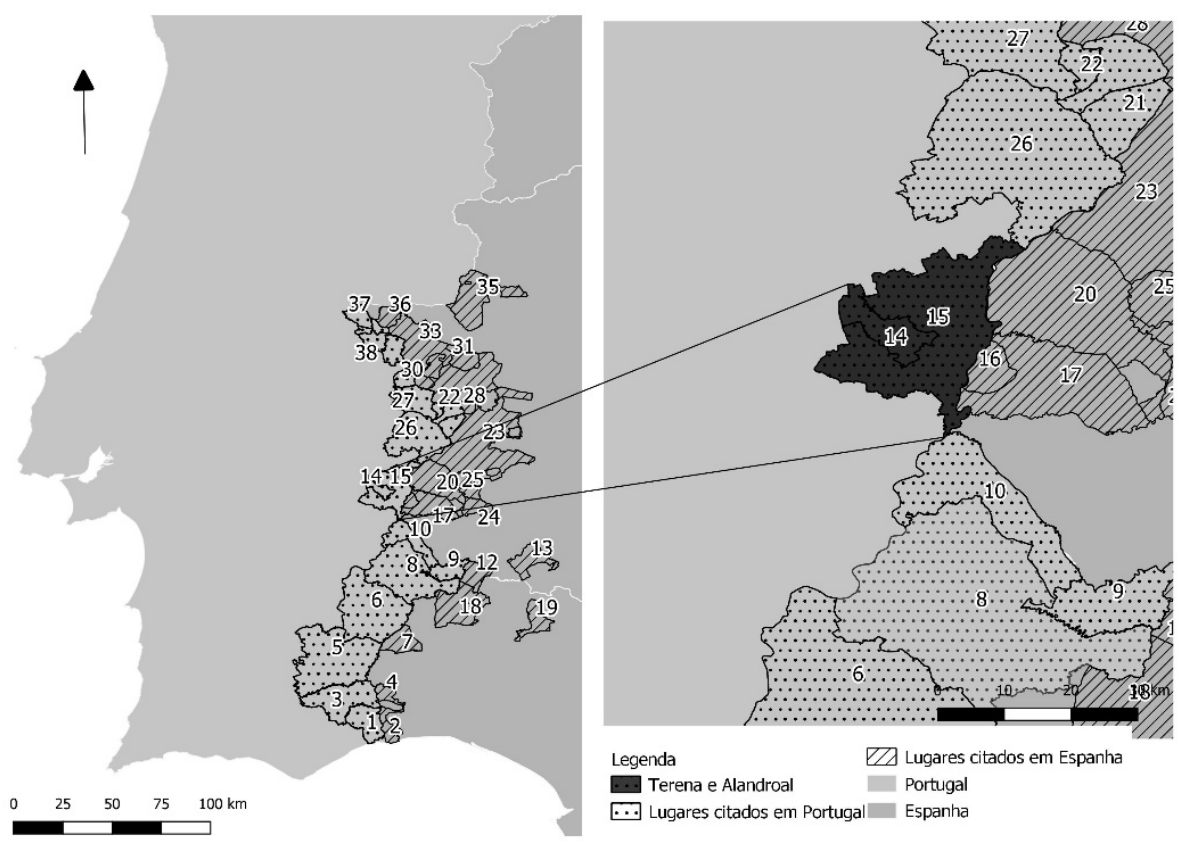

1 Castro Marim, 2 Aiamonte, 3 Alcoutim, 4 San Lúcar de Guadiana, 5 Mértola, 6 Serpa, 7 Paimogo, 8 Moura, 9 Noudar e Barrancos, 10 Mourão, 11 Aroche, 12 Ensinasola, 13 Fregenal, 14 Terena, 15 Alandroal, 16 Cheles, 17 Alconchel, 18 Aroche, 19 Aracena, 20 Olivença, 21 Campo Maior, 22 Ouguela, 23 Badajoz, 24 Barcarrota, 25 Valverde, 26 Elvas, 27 Arronches, 28 Albuquerque, 29 Alegrete, 30 La Codosera, 31 Maiorga, 32, Marvão, 33 Valência de Alcântara, 34 Meadas, 35 Alcântara, 36 Herrera. 37 Montalvão, 38 Castelo de Vide

\section{OLIVENÇA A ARRONCHES: A CONTENDA COM BADAJOZ E ALBUQUERQUE}

Pelo tratado assinado em Alcanices, Castela acordava manter Aroche e Aracena e entregar a Portugal Olivença, Campo Maior e Ouguela ${ }^{97}$. Desde esse

\footnotetext{
${ }^{96}$ A autoria do Mapa 5 é de Helena Albuquerque.

${ }^{97}$ González Jiménez, «Conflictos fronterizos», p. 195.
} 
momento a fronteira afirmou-se e desenvolveu as suas relações. Olivença dirigiu a sua energia colaborativa e de sociabilidade em direção a Juromenha e Elvas e a ofensiva/defensiva rumo a Badajoz. Toda a sua estrutura urbana está assim orientada $^{98}$.

\section{Mapa 6. De Olivença a Arronches ${ }^{99}$.}

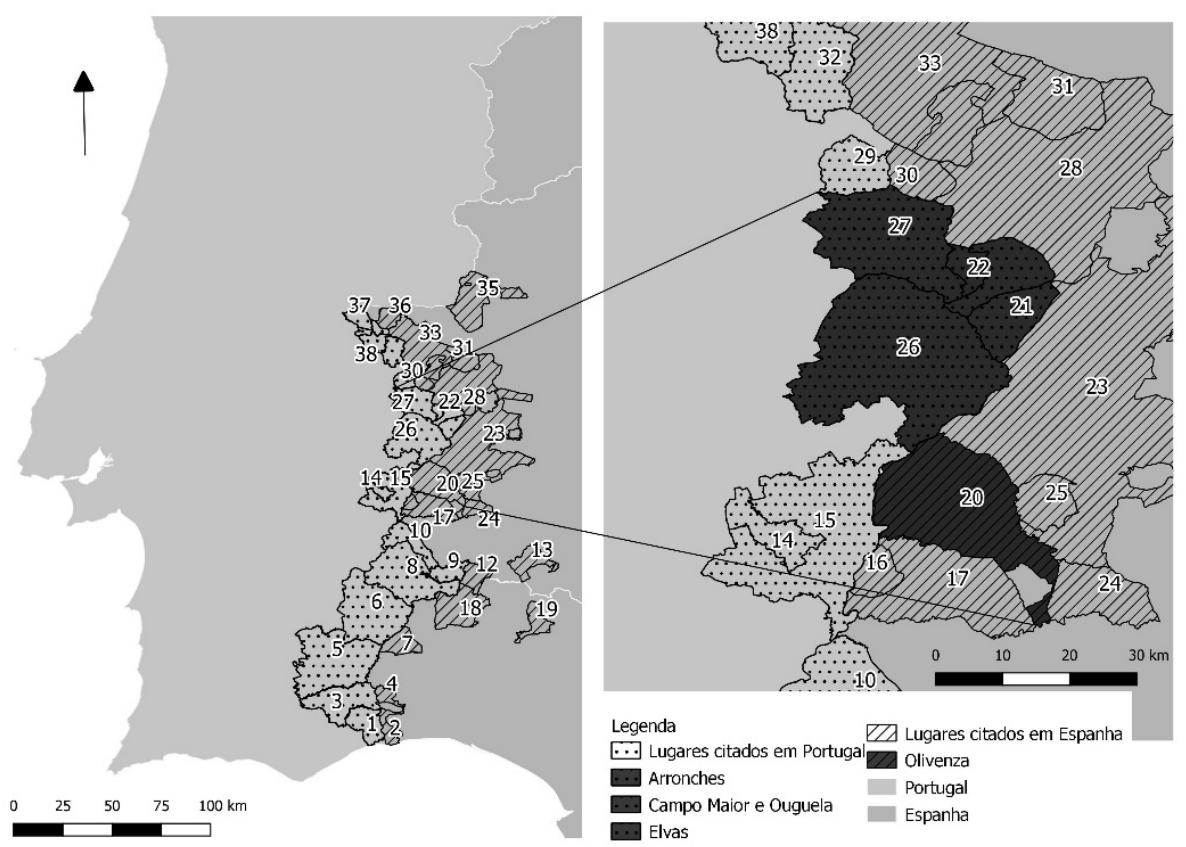

1 Castro Marim, 2 Aiamonte, 3 Alcoutim, 4 San Lúcar de Guadiana, 5 Mértola, 6 Serpa, 7 Paimogo, 8 Moura, 9 Noudar e Barrancos, 10 Mourão, 11 Aroche, 12 Ensinasola, 13 Fregenal, 14 Terena, 15 Alandroal, 16 Cheles, 17 Alconchel, 18 Aroche, 19 Aracena, 20 Olivença, 21 Campo Maior, 22 Ouguela, 23 Badajoz, 24 Barcarrota, 25 Valverde, 26 Elvas, 27 Arronches, 28 Albuquerque, 29 Alegrete, 30 La Codosera, 31 Maiorga, 32, Marvão, 33 Valência de Alcântara, 34 Meadas, 35 Alcântara, 36 Herrera. 37 Montalvão, 38 Castelo de Vide

Vila muito significativa para os domínios portugueses, junto com Campo Maior e Elvas, formava um complexo de defesa face a Badajoz, Cheles, Alconchel, Barcarrota, Higuera de Vargas ou Valverde ${ }^{100}$. Assim o permite visualizar Duarte d'Armas. Nos seus desenhos salienta-se a importância da vila como sistema defensivo face à cidade de Badajoz. Componentes deste sistema são o fosso envolvente da muralha que Duarte d'Armas caracteriza como muito forte e sempre

\footnotetext{
${ }^{98}$ Barros, «Alterações urbanísticas», p. 159-174.

${ }^{99}$ A autoria do Mapa 6 é de Helena Albuquerque.

${ }^{100}$ Pizarro Gomez, «Olivenza: modelo de transferencias».
} 
cheio de água, e as atalaias que retrata em locais bem elevados de forma a dominar as operações organizadas vindas de Castela.

O castelo da vila, cuja construção se inicia no reinado de D. Dinis ${ }^{101}$, domina a região e a atenção dos monarcas é dispensada ao confronto militar na área. Território de risco, Olivença vai crescendo e orientando a sua ação defensiva e ofensiva face às praças-fortes castelhanas mais imediatas ${ }^{102}$.

O termo de Olivença é atravessado por diversos cursos de água: Rio Guadiana, Ribeira de Olivença, Ribeiro da Murteira, Ribeiro de Taligão, Ribeiro de Táliga, Ribeiro dos Calvos, Ribeiro da Nateira e outros que the conferem uma fertilidade quer em pastos quer nas semeaduras cerealíferas, anunciadas pela presença constante de moinhos. Incluído nas áreas de transumância e de pastos, por aqui registam-se desacatos entre vizinhos que provocam destruição de semeaduras e roubos diversos ${ }^{103}$.

A documentação regista tentativas de resolução de conflitos, abertos pela falta de identificação do território. No século XIV, mais precisamente em 1347, juntamse na Ribeira de Táliga e na Serra de Porcas os procuradores e vizinhos de Olivença com os representantes de Alconchel para delimitarem os termos. Em 1353, a questão continua e reabre-se a delimitação de termos entre Badajoz e Olivença ${ }^{104}$. Em meados do século XV registam-se novas questões entre Olivença e Vila Nova de Barcarrota, colocadas em torno das passagens dos gados. Nova missão de delegações portuguesas e castelhanas se verifica ${ }^{105}$.

Elvas, um pouco mais a norte, divide-se também pelo meio do fio dos rios Guadiana e Caia. No século XVI, não se registam contendas desta vila com Badajoz. Sabemos, no entanto, por Margarida Garcês Ventura ${ }^{106}$, que a situação foi de grandes conflitos no passado. A autora refere um capítulo das cortes de 1439, no qual se alude a Elvas como o local onde se acolhiam as forças militares dos lugares dos extremos. Por esse motivo, o rei de Castela ordenara que Badajoz tivesse sempre gente a cavalo, pronta para qualquer eventualidade. Do lado português, o rei D. Duarte repetia a ordem aos moradores da vila: estarem sempre preparados com cavalos e armas. Os procuradores às mesmas cortes referem as inúmeras conflitos que se levantavam entre os vizinhos de Elvas e os de Badajoz ${ }^{107}$.

Alguns anos mais tarde, nas cortes de 1459, assinala-se o crescente perigo castelhano resultante dos inúmeros privilégios dados a quem fosse morar para Badajoz. Após a concessão destes privilégios, regista-se um aumento de 400 vizinhos de Badajoz para 1000. Relata-se que vinham gentes de outros lugares de

\footnotetext{
${ }^{101}$ Marques, «D. Afonso IV e a construção do castelo de Olivença», p. 59-80.

102 Para entender todo o processo de evolução urbana, em especial o operado no reinado de D. Dinis como defesa face a Castela, ver Pizarro Gómez, «Olivenza: Modelo de transferencias», p. 79-87.

${ }^{103}$ Demarcações de Fronteira: De Castro Marim, p. 111.

${ }^{104}$ Martín Martín, «La tierra de las “contiendas”», p. 283.

${ }^{105}$ Ibid., p. 284.

${ }^{106}$ Ventura, «Os coutos de homiziados», p. 605-606.

${ }^{107}$ Ibid.
} 
Castela, de Navarra e de Aragão para povoar a região e usufruir das suas vantagens ${ }^{108}$. A concentração anuncia o incremento de dificuldades nas relações, mas revela que a fronteira portuguesa pode constituir um forte atrativo.

Elvas desempenha papel fundamental na divisão com o reino vizinho que se demarca pelo rio Guadiana e pelo Caia. As inúmeras ribeiras e lezírias, citadas a par e passo na documentação, permitem o cultivo de cereais, atestado pela presença intensa de moinhos. Região de passagem, liga-a a Badajoz um caminho que cruza o rio Caia em áreas de vaus ${ }^{109}$.

Mendo Afonso de Resende preocupou-se na inquirição que promoveu com os possíveis desvios do rio Caia em áreas de fronteira, apoiado em narrativas de inquiridos, que referiam que no local da Ribeira Velha, o Caia se escancalha muito $^{110}$. Por aqui a água corre com grande força pela paisagem, chegando a mudar a fisionomia do terreno por onde passa e destruir tapamentos e desvios feitos pelo homem para a controlar ${ }^{111}$.

Por aqui passam caminhos que ligam os principais povoados, o que permite registar que as atividades económicas da região continuam inabaláveis apesar da contenda. Ana Maria Pereira Ferreira identifica Elvas e Olivença como os grandes entrepostos comerciais nas ligações portuárias secas a Castela ${ }^{112}$. A reforçar a existência destas ligações, Alfonso Franco Silva, com base em documento existente no arquivo local, assinala a passagem de uma barca para Elvas e refere o porto seco de Olivença por onde passavam o gado, peixe, vinho, panos, cereais e outros produtos agrícolas $^{113}$.

Ao invés do registado para Olivença, por terras de Campo Maior e Badajoz registam-se conflitos continuados: fala-se desvios de marcos e dá-se uma atenção muito especial à marcação em terra, sempre mais perecível que a ribeirinha.

Campo Maior parte com termos de Badajoz. Nestes lugares a fronteira dividese pelas ribeiras de Caia, Xévora e Bótoa. O conflito que marcou estas vilas reporta a narrativas recentes, como o carvalho a que retiraram a casca por se encontrar marcado com quinas, marcos desviados, ou ainda marcos escondidos entre o mato.

Desde 1369 que os moradores de Campo Maior têm privilégios de porte de armas para defesa de salteadores e criminosos vindos de Castela ${ }^{114}$. Esta concessão de porte de arma entende-se como a "militarização da sociedade fronteiriça" e comprova que a fronteira em determinados locais é alvo de assaltos constantes ${ }^{115}$.

Atravessada por Caia, Xévora e Bótoa, a paisagem de Campo Maior marca-se pela diversidade de flora onde os matos bravos, freixos, azinhais, chaparrais,

\footnotetext{
108 Ibid..

${ }^{109}$ Demarcações de Fronteira: De Castro Marim, p. 89, 90.

${ }^{110}$ Ibid., p. 90.

111 Ibid., p. 95.

${ }^{112}$ Ferreira, A importação e o comércio têxtil.

${ }^{113}$ Franco Silva, «La villa portuguesa de Olivenza», p. 514.

${ }^{114}$ Ventura, «Os coutos de homiziados», p. 607.

${ }^{115}$ Martín Martín, «La tierra de las “contiendas”», p. 290.
} 
pereiros, enxarais, aroeirais, espinheiros e outra vegetação rasteira intensa se mistura com terras agrícolas, de cereal e pastos. Na Ribeira de Xévora encontram-se várias ilhas: ilha do Marco, ilha do Tesoureiro, ilhas de Afonso Mexia, entre outras, reguladas por usos e costumes e delimitadas pela presença de marcos.

As várias referências a caminhos permitem verificar que a região é de grande movimento económico: o caminho que vai de Táliga para Vila Nova de Barcarrota, o caminho que vai para Mesa, o caminho velho para Badajoz, também designado de Caminho Galego, o caminho de Santa Engrácia, o caminho de Brás Afonso, o caminho da Godinha e a carreira de cavalo. A distância por estes caminhos conta-se por passadas de cavalo ou por tiros de besta ${ }^{116}$.

Nestas vias de comunicação, o sítio designado de Chico Salto é um local a evitar. Este local é referenciado por José Luís Martín Martín a partir de um documento das Gavetas da Torre do Tombo datado de 1332. Esclarece que Chico é um pastor chamado de Pero Chico, dono de uns currais ${ }^{117}$. Ora, pastor e salteador, como referem as demarcações, o local onde operava recebeu o seu nome e mantémse como um bom local para se produzirem assaltos.

Duarte d'Armas registou as atalaias de observação a Badajoz que permitem criar uma rede continuada de sistemas defensivos muito próximos que possibilitam uma comunicação e uma ação rápida de reforço militar ${ }^{118}$.

Ouguela divide o termo com Badajoz e Albuquerque, terra de pasto e de cereais, de lagoas artificiais para o gado, sobreiros, marmeleiros, carvalhos ${ }^{119}$, salgueiros, murtas, sobreiros, aroeiras, pereiros, azinheiras, freixieiros e azambujeiras, onde cervos, grous, águias e muitos pombais. A Ribeira de Xévora, a Ribeira de Ouguela e o Ribeiro do Salgueiro, mantêm uma área de pescas ativa.

Assinalam-se contendas com Albuquerque. Em 1410, um documento datado de 23 de Julho mostra que as vilas de Ouguela e Albuquerque nomearam procuradores para demarcar os termos ${ }^{120}$. As demarcações pelas ribeiras de Xévora, Ouguela, Marmeleiro e Abrilongo, pelos marcos ou outros pontos estratégicos, como edifícios arruinados, lagoas, árvores, caminhos e cursos de água, marcam a linha de fronteira. Os marcos são geralmente de pedra, fala-se em mármore, mas há referências a marcos produzidos de uma argamassa de pedra e terra.

Segundo se compreende do arrolamento de documentos que Mendo Afonso de Resende identifica como existentes nos cofres da vila, nem sempre por aqui se viveu a paz.

Arronches faz fronteira com Albuquerque, tem paisagem idêntica a Ouguela, mas regista-se um aumento de fragas e penedias que dificultam a circulação em

\footnotetext{
${ }^{116}$ Demarcações de Fronteira: De Castro Marim, p. 90.

${ }^{117}$ Martín Martín, «La tierra de las “contendas”», p. 287.

${ }^{118}$ Barroca, «D. Dinis», p. 810-812.

${ }^{119}$ Referidos na fonte pelo nome de "encina".

${ }^{120}$ Gavetas da Torre do Tombo, vol. IX (Gav. XVIII, maços 7-13), Gav. XVIII, m.11, doc.1, p. 570581.
} 
determinadas áreas. As ribeiras de Abrilongo e de Ouguela assumem a demarcação com Castela.

Por Arronches passa o caminho que une Alegrete a La Codosera. Outro caminho, referido em mau estado, o que aponta para falta de manutenção, une Alegrete a Valencia de Alcântara. Outro caminho une Alegrete a La Rabaza, uma estrada une Alegrete a Valência de Alcântara, Albuquerque, La Codosera e Mayorga. A presença de vias de comunicação declara uma área de trânsito comercial mais intenso, mas sujeito a assaltos e conflitos. Por se encontrarem em área de risco, os habitantes de Arronches adquirem privilégio de porte de arma, em 1429. Pretendiam manter ativa a defesa da fronteira com Castela, nomeadamente com La Codesera e Albuquerque, vilas com as quais se manifestam mais contendas $^{121}$.

\section{TERRAS DE RELACIONAMENTOS MENOS DIFÍCEIS: DE ALEGRETE AO TEJO}

A chegada ao Tejo revela um convívio mais pacífico, apesar do passado de contenda por questões de passagens de gados e uso de terras.

Alegrete parte com La Codosera e Mayorga. Por aqui a vegetação é de amieiros, sobreiros e matos. Muda novamente a paisagem, tornando-se um pouco mais agreste. A fronteira marca-se em terra pelas serras, em locais por onde as marcações são duvidosas.

Fronteira difícil desde o século XIII registam-se contendas em torno das pastagens e da disputa de uma lagoa que serve de bebedouro de gado ${ }^{122}$. Apesar de um passado de difícil relacionamento, no século XVI não se registam conflitos. Os vizinhos de ambos os lados da fronteira têm boa amizade e vizinhança. Pastam os gados em paz num e noutro termo. Têm acordado os concelhos de Alegrete e La Codesera que se os gados portugueses forem encontrados em terras castelhanas os portugueses pagam 60 reais por rebanho e podem caçar livremente no termo de Alegrete, e vice-versa ${ }^{123}$.

Os conflitos aos quais alude José Luis Martín ${ }^{124}$, entre Marvão e Valencia de Alcântara no que toca ao aproveitamento de pastos, em 1336 parecem sanados pelos constantes acordos que se foram produzindo desde então. As demarcações contam sete compromissos de vizinhança acordados em 1488, 1498, 1500, 1512 e 1515.

\footnotetext{
${ }^{121}$ Ventura, «Os coutos de homiziados», p. 605, 606.

${ }^{122}$ Martín Martín, «La tierra de las “contiendas”», p. 280.

${ }^{123}$ Demarcações de Fronteira: De Castro Marim, p. 152.

${ }^{124}$ Martín Martín, «La tierra de las “contiendas”», p. 283.
} 


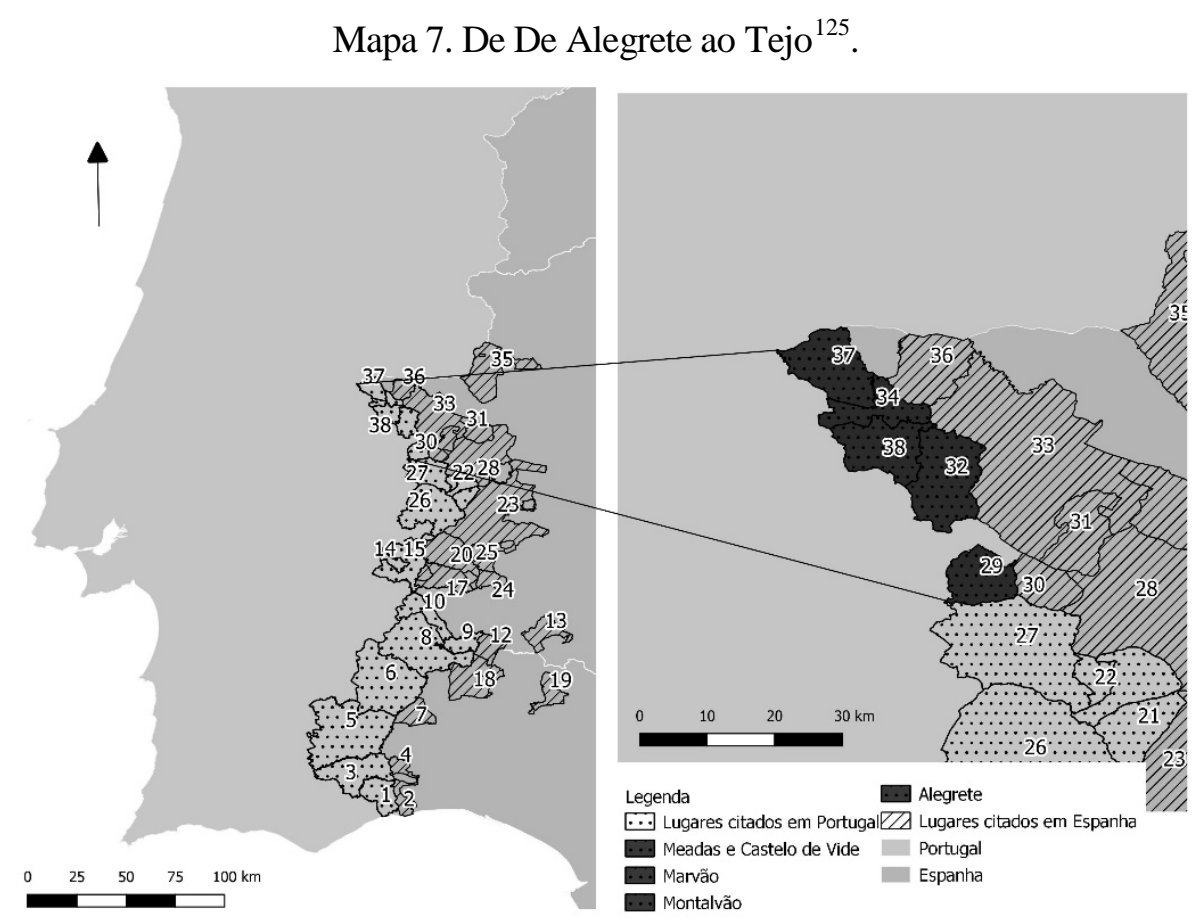

1 Castro Marim, 2 Aiamonte, 3 Alcoutim, 4 San Lúcar de Guadiana, 5 Mértola, 6 Serpa, 7 Paimogo, 8 Moura, 9 Noudar e Barrancos, 10 Mourão, 11 Aroche, 12 Ensinasola, 13 Fregenal, 14 Terena, 15 Alandroal, 16 Cheles, 17 Alconchel, 18 Aroche, 19 Aracena, 20 Olivença, 21 Campo Maior, 22 Ouguela, 23 Badajoz, 24 Barcarrota, 25 Valverde, 26 Elvas, 27 Arronches, 28 Albuquerque, 29 Alegrete, 30 La Codosera, 31 Maiorga, 32, Marvão, 33 Valência de Alcântara, 34 Meadas, 35 Alcântara, 36 Herrera. 37 Montalvão, 38 Castelo de Vide

A mesma paisagem e as mesmas dificuldades prolongam-se para Meadas, lugar que conta apenas uma casa-torre e duas outras casas. Localizado na fronteira nas partidas com Alcântara e com Herrera, estava despovoada. Até ao Tejo a paisagem mantem-se e em Montalvão a fronteira com a vila de Herrera continua a definir-se por ribeiras de vales inóspitos e terras fragosas, onde as serranias afastam. A leitura das demarcações das terras de Alegrete, Marvão, Castelo de Vide e Medas é elucidativa quanto á inexistência de povoados nestas zonas. A fronteira demarcase exclusivamente por elementos naturais, em locais onde é difícil de encontrar referências que permitam identificar a passagem dessa mesma fronteira. Multiplicam-se as menções a penedias, cumes, cabeços, serras, ribeiros, veredas, ladeiras, entre outros. Os caminhos vão cortando a terra árida, anunciadores de trilhos difíceis e inseguros que ligam portos e permitem, a quem arrisca, comunicar.

${ }^{125}$ A autoria do Mapa 7 é de Helena Albuquerque. 
Ao explorar este percurso a par e passo verificamos, assim como Armindo de Sousa, que os rios unem, como estradas que são, aumentando os contactos quotidianos e as possibilidades de uma sociabilidade que alterna entre $\mathrm{o}$ entendimento e o desentendimento, e as serranias afastam, diminuindo os contactos e as possibilidades de contenda ${ }^{126}$.

\section{CONCLUSÃo}

Como conclusão, e para responder à questão inicialmente colocada e que pretendeu orientar este estudo: como se vivia e convivia em terras por onde a fronteira separava as gentes, e quais os cenários que acompanhavam o quotidiano de uma linha de demarcação? Será possível demonstrar como a paisagem e a localização geográfica associadas às questões históricas de relações influenciam e regem as atividades económicas e o convívio social.

Em terras raianas, as relações de convívio caracterizam-se por conflitos surgidos lado a lado com laços familiares e de amizade. As duas facetas desta relação permitem a continuidade das conexões económicas, uma por garantir o estabelecimento de normativas, regulamentos e uma fiscalidade ativa, a outra por garantir a sociabilidade e o bem-estar necessários. Na mesma fronteira registam-se anos de paz e períodos de conflito, espaços de paz e espaços de conflito ${ }^{127}$.

Certo é que a presença da fronteira mostra-se uma constante no imaginário do homem medieval, que desceu do norte a habitar estes locais. A linha está lá, sentese, não se vê, ou vê-se apenas nos marcos e nas normativas, sabe-se que divide poderes, senhorios, pessoas e terras e marca negativamente ou positivamente $\mathrm{o}$ convívio $^{128}$. Dificilmente se esquece, inclusive em áreas onde as populações vivem maior proximidade. Zonas há em que transpô-la pode levar à morte, outras onde transpô-la pode conduzir à família e a amizades mais próximas. Os episódios vão marcando o quotidiano e construindo a história dos locais.

As maiores vítimas dessas relações acabam por ser os marcos, os malhões, assinalados por símbolos identificadores de posse dos reinos, as construções e as colheitas que se encontram sob constante ameaça.

Seria possível questionar se no momento do derrube do marco ou da vingança face a esse derrube, a ação resulta da existência ou não de um movimento/sentimento nacionalista no qual a fronteira, a tal linha invisível, é a marca que separa o reino de Portugal de Castela. Será possível afirmar que o conflito assenta na posse da terra, o mesmo sentimento de posse que facilmente se transporta para o campo emocional que divide outras terras entre outros vizinhos ${ }^{129}$.

\footnotetext{
${ }^{126}$ Sousa, «Fronteira e representação parlamentar ».

${ }^{127}$ Freitas, «Viver e conviver em terras raianas», p. 475-483.

${ }^{128}$ Magalhães, «Fronteras y espacios». Armindo de Sousa também o abordou mas não concluiu sobre esta questão. Sousa, «Fronteira e representação parlamentar», p. 53.

${ }^{129}$ Sousa, «Fronteira e representação parlamentar», p. 54.
} 
A demarcação da fronteira e os compromissos de vizinhança estabilizam as relações locais. É importante saberem por onde passa a linha raiana e como os homens se devem orientar e reger nas suas terras, para evitar conflitos.

Fisicamente delimitam a fronteira pedras amontoadas, ferros cravados em pedras, quinas bem desenhadas, arcas que guardam pedras marcadas com simbologia, fontes, quedas de água, poços, ruínas, águas vertentes, cabeços ou outras ocorrências geográficas; e no momento da demarcação, mostraram-se imprescindíveis para parar o conflito. Com frequência, os elementos naturais são explorados na demarcação da fronteira. Alguns pouco sustentáveis como árvores, outros perenes como grandes penedos de cor que sobressaiam na paisagem, geralmente em mármore rosa ou branco.

Sempre que os rios, de qualidade perene ${ }^{130}$, conforme alude a fonte das demarcações de fronteira, cruzam os territórios, a delimitação é mais fácil e deixa menos questões a resolver. A linha passa pelo fio do meio do rio ${ }^{131} \mathrm{e}$ as margens são amplamente exploradas até metade do caudal. No entanto, mesmo nestes casos de maior segurança na divisão, ainda se registam conflitos em torno da posse total do caudal que beneficiava a cobrança de impostos e o uso de barcas. Por vezes a fronteira não passa pelo meio do rio, pode ir até à margem contrária ${ }^{132}$. Nestes casos as questões agudizam-se.

Delimitam, ainda, a fronteira serras áridas e inóspitas que criam espaços vazios e intransitáveis, onde vivem espécies como o javali, o coelho, o urso, a cabra montês, o lobo e a raposa ao lado dos domesticados cavalos, asnos, gado vacum, gado ovino e suíno ${ }^{133}$. Nesse caso, conforme refere Armindo de Sousa, a linha fronteiriça alarga-se a um espaço amplo e deserto, uma terra de ninguém, uma "fronteira-zona" 134 .

Ao colocar lado a lado a paisagem e as questões de fronteira, verifica-se que entre as duas existe uma ligação intrínseca, em particular no que respeita à hidrografia e à natureza dos solos. A importância da água neste contexto é assinalável. Os rios, riachos, ribeiros, charcos, fontes são sempre descritos como elementos fundamentais na demarcação. As descrições físicas da geografia local, fauna, flora, construções, descrições de marcos e malhões, acrescidas de narrativas de gentes locais, completam o quotidiano raiano tardo-medieval com grande número de informações.

As descrições da fronteira podem ser agrupadas em diversas dimensões. Descrição da fauna, da flora, da toponímia local, de inúmeros elementos de património natural e construído, descrições de sociabilização e de relação humana

\footnotetext{
${ }^{130}$ Entende-se de maior caudal e de leito com percurso inalterável, assinalados em diversos locais nas Demarcações de Fronteira: De Castro Marim.

${ }^{131}$ Linha do meio do rio, conforme foi já referida e sempre assinalada nos rios a que as demarcações fazem alusão.

${ }^{132}$ Caso já referido para Castro Marim e Alcoutim.

133 Araújo, «Relações de fronteira», p. 229-240.

${ }^{134}$ Sousa, «Fronteira e representação parlamentar», p. 55.
} 
local. Anota-se uma preocupação fundamental pela descrição objetiva de forma a ser perfeitamente compreendida por quem analise os relatos. Esta preocupação permitiu que na contemporaneidade usufruíssemos de uma descrição plena do que era a fronteira e qual o estado das suas relações no século XVI.

Depois de analisada a questão inicial que nos permitiu refletir e concretizar este breve estudo, [Como se vivia e convivia em terras por onde a fronteira separava as gentes, e quais os cenários que acompanhavam o quotidiano de uma linha de demarcação?], fica a pairar uma outra reflexão que se releva de grande importância: a demarcação física, visual, efetuada pelos observadores e enviados régios (Duarte de Armas e Mendo Afonso de Resende), objetiva a paisagem geográfica, cultural, política e social que as regiões fronteiriças vivem na sua relação com o reino vizinho.

A metodologia de diagnóstico do território usada pelos emissários, insere o leitor e o participante da inquirição na observação geográfica e social mais rigorosa e de interesse para o poder político central, para a demarcação do seu território e para a sua decisão. Refira-se, mais rigorosa que a cartografia ou outras descrições geográficas de território que frequentemente não referem a verdadeira localização ou criam ilusões e descrevem territórios imaginados ${ }^{135}$.

Ressalva-se que mesmo que não seja uma demarcação presencial, note-se que algumas vezes Mendo Afonso de Resende não vai ao lugar onde o marco se encontra, o ouvir das gentes locais sobre a demarcação ou a leitura de documento em arquivo no local, reproduz um mesmo objetivo de efetivar a presença do rei e do poder político central, acompanhado de uma leitura de paisagem social local de grande interesse para o poder central.

Neste contexto Zayde Antrim ${ }^{136}$ apelida a descrição do território, em textos similares aos que neste estudo se referem, de o dicurso do lugar. Os lugares são descritos não apenas como um cenário onde a ação se desenrola. Reforça a autora, que o discurso dos lugares funciona como um veículo para estimular a vinculação ao território.

Estamos perante uma conclusão de nota. Os livros de demarcações de fronteira ou de registo do estado das fortalezas na região de fronteira são, também, elementos claros de reforço da vinculação ao território. As descrições das áreas de conflito ou de paz e da sua contextualização histórica fundamentam a criação de vínculos que se solidificam pela partilha, pela visita, pela inquirição, pela recolha do documento antigo nos cofres locais, que coloca na mesma sala um discurso local de debate político de separação real das terras vizinhas.

Ao explorar estas fontes que nos permitem visualizar a paisagem medieval, uma outra reflexão impele a verificar as grandes alterações paisagísticas que decorreram até aos dias de hoje neste território. Um novo trabalho poderá trazer novas conclusões. Da mesma forma, continuar para norte será, sem dúvida, um

\footnotetext{
${ }^{135}$ Hamilton; Angelov; Atanasov; Millones, «Fluid Borders».

${ }^{136}$ Antrim, Routes and Realms.
} 
descobrir de novas paisagens e de novas sociabilidades. Aliciante é visitar este espaço, estas terras e verificar o que os dias de hoje nos podem mostrar. Semelhanças? Diferenças? A mesma aridez? Os mesmos percursos ainda estarão visíveis?

\section{FONTES PUBLICADAS}

Demarcações de Fronteira: De Castro Marim a Montalvão, Coordenação Humberto Baquero Moreno, Introdução, índices e revisão paleográfica de Isabel Vaz de Freitas. Porto, Centro de Investigação e Documentação de História Medieval, Porto, Universidade Portucalense, 2003, vol. I.

Demarcações de Fronteira: Lugares de Trás-os-Montes e de Entre-Douro-eMinho. Coordenação Humberto Baquero Moreno, índices e revisão paleográfica de Isabel Vaz de Freitas. Porto: Centro de Investigação e Documentação de História Medieval; Universidade Portucalense, vol. III, 2003

Duarte D’ Armas, Livro das fortalezas de Duarte d' Armas. Estudo introdutório e leituras de João José Alves Dias, Caleidoscópio, 2016.

Gavetas da Torre do Tombo. Lisboa, Centro de Estudos de História Ultramarina, 1971, vol. IX.

\section{BIBLIOGRAFÍA}

Abulafia, David; Berend, Nora (eds.), Medieval Frontiers: Concepts and Practices, NY, Routledge, 2016. DOI: https://doi.org/10.4324/9781315249285.

Andrade, Amélia Aguiar, A Construção Medieval do Território, Lisboa, Livros Horizonte, 2001.

Andrade, Amélia Aguiar; «Entre Lima e Minho e Galiza na Idade Média: uma relação de amor e ódio», Revista da Faculdade de Letras [Carlos Alberto Ferreira de Almeida, In Memoriam], Porto, Faculdade de letras da Universidade do Porto, 1999, I, pp. 77-91.

Antrim, Zayde, Routes and Realms: The Power of Place in the Early Islamic World, Oxford, Oxford University Press, 2012.

DOI: https://doi.org/10.1093/acprof:oso/9780199913879.001.0001. 
Araújo, Julieta, «Relações de fronteira na Idade Média: A transumância», en $I V$ Jornadas Luso-Espanholas de História Medieval. As Relações de Fronteira no século de Alcañices, Porto, 1998, vol. 1, pp. 229-240.

Ayala Martínez, Carlos de, «Frontera castellano-portuguesa y Órdenes Militares. Problemas de jurisdicción (ss. XII-XIII)», en Alvaréz Palenzuela, Vicente (ed.), Jornadas de Cultura Hispano-portuguesa. Interrelación cultural en la formación de una mentalidad. Siglos XII al XVI, Madrid, Universidad Autónoma de Madrid, 1999, pp. 51-92.

Barroca, Mário, «D. Dinis e a arquitetura militar portuguesa», Revista da Faculdade de Letras. História, 1998, série I, vol. 15, pp. 801-809. URL: https://ojs.letras.up.pt/index.php/historia/article/view/5583.

Barros, Amândio, «Alterações urbanísticas em Faro e Olivença na segunda metade do século XV», Revista da Faculdade de Letras. História, 1986-1987, série I, vol. 7, pp. 159-174. Handle: http://hdl.handle.net/10216/13569.

Bartlett, Robert; MacKay, Angus (eds.), Medieval Frontiers Societies, Oxford, Oxford University Press, 2011.

Borrero Fernández, Mercedes, «Los lugares de Fregenal, tierra de Sevilla, en el siglo XV», En la España Medieval, 1980, $\mathrm{n}^{\circ}$ 1, pp. 17-29. URL: https://revistas.ucm.es/index.php/ELEM/article/view/ELEM80801100 $\underline{17 \mathrm{~A}}$.

Borrero Fernández, Mercedes, «Situación demográfica de la sierra al norte de Sevilla (siglos XV a 1534)», Historia. Instituciones. Documentos, 1998, ${ }^{\circ}$ 25, pp. 43-71.

URL: https://revistascientificas.us.es/index.php/HID/article/view/4369.

Carmona Ruiz, María Antonia, «La explotación ganadera de la frontera luso española: la "contienda” de Moura, Noudar, Aroche y Encinasola», Revista da Faculdade de Letras. História, 1998, série I, vol. 15, pp. 241-257. URL: https://ojs.letras.up.pt/index.php/historia/article/view/5554.

Carriazo Rubio, Juan Luis, «Pesca, frontera y señorío: Ayamonte, de la Edad Media a la Edad Moderna», en Huelva en su Historia, 2001, nº 8, pp. 41- 66.

Carriazo Rubio, Juan Luis, «Violencia y relaciones fronterizas: Alcoutim y Sanlúcar de Guadiana a fines del siglo XV», Revista da Faculdade de Letras. 
História, 1998, série I, vol. 15, pp. 365-382. URL: https://ojs.letras.up.pt/index.php/historia/article/view/5561.

Cayetano Rosado, Moisés, «Fortificaciones abaluartadas de la raya hispanoportuguesa», Revista de Estudios Extremeños, 2010, Tomo LXVI, Número II, pp. 789-804.

Costa, Paula Pinto, «Ordens Militares e Fronteira: um desempenho militar, jurisdicional e político em Tempos Medievais», Revista da Faculdade de Letras. História, 2006, III série, vol.7, pp. 79-91. URL: https://ojs.letras.up.pt/index.php/historia/article/view/3762.

Duarte, Luís Miguel, «Contrabandistas de gado e "passadores de cousas defesas" para Castela e "terra de mouros», en IV Jornadas Luso-espanholas de historia Medieval. As relações de fronteira no século de Alcanices, Porto, 1998, vol. I, pp. 451-473.

Duarte, Luís Miguel, «Garcia de Melo em Castro Marim: a atuação de um alcaidemor no início do século XVI», en III Jornadas de História Medieval do Algarve e Andaluzia, Loulé, 1987, p. 131-149.

Ferreira, Ana Maria Pereira, A importação e o comércio têxtil em Portugal no século XV (1385 a 1481), Lisboa, Imprensa Nacional- Casa da Moeda, 1983.

Franco Silva, Alfonso, «La villa portuguesa de Olivenza en la Baja Edad Média: Un arancel de aduana dado por D. Manuel I em 1510», En la España Medieval, 1987, vol. 10, pp. 509-532. URL: https://revistas.ucm.es/index.php/ELEM/article/view/ELEM8787110509A

Freitas, Isabel Vaz de, «A água no Livro das Fortalezas de Duarte d'Armas», en Martins, Manuela; Freitas, Isabel Vaz de; Val Valdivieso, Isabel del (coords.), Caminhos da água: Paisagens e usos na longa duração, Braga, CITCEM, 2012, pp. 163-177.

Freitas, Isabel Vaz de, «Caminhos que cruzam fronteiras», en Fonseca, Luis Adão da; Amaral, Luís Carlos; Santos, Maria Fernanda (coords.), Os Reinos Ibéricos na Idade Média: Livro de Homenagem ao Prof. Doutor Humberto Carlos Baquero Moreno, Porto, Civilização, vol. I, pp. 493-499.

Freitas, Isabel Vaz de, «Viver e conviver em terras raianas na Idade Média», en As relações de fronteira no século de Alcanices: Atas das IV Jornadas Luso- 
espanholas de História Medieval, Revista da Faculdade de Letras. História, 1999, série I, vol. 15, pp. 475-483.

Freitas, Isabel Vaz de, Mercadores entre Portugal e Castela na Idade Média, Oviedo, TREA, 2009.

Galán Parra, Isabel, «El linaje y los Estados señoriales del Duque de Medina Sidonia a comienzos del siglo XVI», En la España Medieval, 1988, $\mathrm{n}^{0} 11$, pp. 45-78.

URL: https://revistas.ucm.es/index.php/ELEM/article/view/ELEM8888110045A

García Fernández, Manuel, «La Política Internacional de Portugal y Castilla en el contexto peninsular del Tratado de Alcañices: 1267-1297: Relaciones diplomáticas y dinásticas», en IV Jornadas Luso-Espanholas de História Medieval, As Relações de Fronteira no Século de Alcanices, Porto, Universidade do Porto, 1998, pp. 903-943.

González Jiménez, Manuel, «Conflictos fronterizos en la sierra de Aroche: El pleito de Barrancos (1493)», Huelva en su Historia, 2011, vol. 1, pp. 193-200.

González Jiménez, Manuel, «Relación final», en Ayala Martinez, Carlos de; Buresi, Pascal; Josserand, Philippe (eds), Identidad y representación de la frontera en la España medieval, siglos XI, Madrid, Casa Velázquez - Universidad Autónoma de Madrid, 2001, pp. 293-301.

Hamilton, Stuart E.; Angelov, Alexander; Atanasov, Vladimir; Millones, Marco, «Fluid Borders: Rethinking Historical Geography and Fixed Map Boundaries in Contested Regions», en Professional Geographer, 2016, vol. 68, 1, pp. 115-128. DOI: https://doi.org/10.1080/00330124.2015.1054017.

Ioan, Ianos; Saghin Irina; Valentina, Stoica Ilinca; Daniela, Zamfir, «Perennial values and cultural landscapes resilience», en Procedia - Social and Behavioral Sciences, 122, 2014, pp. 225-229.

DOI: https://doi.org/10.1016/j.sbspro.2014.01.1332.

Jiménez, Alfonso, «Torres, un castillo onubense», en Huelva y su História, 2002, vol. 9, pp. 97-118.

Ladero Quesada, Miguel Ángel, «Reconquista y definiciones de frontera», Revista da Faculdade de Letras. História, 1998, série I, vol. 15, pp. 655-691. URL: https://ojs.letras.up.pt/index.php/historia/article/view/5575. 
Ladero Quesada, Miguel Ángel, «Sobre la evolución de las fronteras medievales hispánicas (siglos XI a XIV)», en Ayala Martínez, Carlos de; Buresi, Pascal; Josserand, Philippe (eds.), Identidad y representación de la frontera en la España medieval, siglos XI, Madrid, Casa de Velázquez - Universidad Autónoma de 2001, pp. 5-51.

Macías González, Santiago, «El problema historiográfico de los Algarves», Revista da Faculdade de Letras. História, 1998, série I, vol. 15, pp. 987-1016. URL: https://ojs.letras.up.pt/index.php/historia/article/view/5506.

Macías González, Santiago, «Moura na Baixa Idade Média: Elementos para um estudo histórico e arqueológico», Arqueologia Medieval, 1993, nº 2, pp. $127-$ 157.

Magalhães, Joaquim Romero de, «Fronteras e espacios: Portugal y Castilla», en Carabias Torres, Ana María (ed.), Las relaciones entre Portugal y Castilla en la época de los descubrimientos, Salamanca, Universidad de Salamanca, 1994, pp. 91-103.

Magalhães, Joaquim Romero, Algarve económico durante o século XVI, Lisboa, Edição Cosmos, 1970.

Marques, José, «D. Afonso IV e a construção do castelo de Olivença», Revista da Faculdade de Letras. História, 1995, série II, vol. 2, pp. 59-80.

Martín-Martín, José Luis, «Conflictos luso-castellanos por la raya», Revista da Faculdade de Letras. História, 1998, série I, vol. 15, pp. 259-272. URL: https://ojs.letras.up.pt/index.php/historia/article/view/5555.

Martín-Martín, José Luis, «La tierra de las “contiendas”: Notas sobre la evolución de la raya meridional en la Edad Media», Norba. Revista de História, 19962003, n 16, 1, pp. 277-293.

Medina García, Eusebio, «Orígenes históricos y ambigüedad de la frontera hispanolusa (La Raya)», Revista de Estudios Estremeños, vol. 62, n², 2006, pp. 713-724.

Medrano, Violeta, Un mercado entre fronteras: Las relaciones comerciales entre Castilla y Portugal al final de la Edad Media, Valladolid, Universidad de Valladolid, 2010. 
Montaña Conchiña, Juan Luis de la, «El comercio de la frontera castellanoportuguesa: El âmbito extremeño (siglos XIII-XV)», En la España Medieval, 2005, $\quad \mathrm{n}^{\circ} \quad 28, \quad$ pp. 81-96. https://revistas.ucm.es/index.php/ELEM/article/view/ELEM0505110081A

Montaña Conchiña, Juan Luis de la, «La guerra en la frontera castellano-portuguesa (siglos XIV-XV)», Norba. Revista de Historia, 2008, vol. 21, pp. 11-28.

Moreno, Humberto Baquero, «As relações de fronteira no século de Alcanices (1250-1350): O tratado de Alcanices», Revista da Faculdade de Letras. História, 1998, série I, vol. 15, pp. 641-653.

URL: https://ojs.letras.up.pt/index.php/historia/article/view/5574.

Moreno, Humberto Baquero, «Relações marítimas e comerciais entre Portugal e a Baixa Andaluzia nos séculos XIV e XV», Estudios de historia y de arqueologia medievales, 1994, vol. 10, pp. 9-24.

Moreno, Humberto Baquero; Freitas, Isabel Vaz de, A corte de Afonso V: O tempo e os homens, Oviedo, TREA, 2009.

Murray, Alan (Ed.), The North-Eastern Frontiers of Medieval Europe: The Expansion of Latin Christendom in the Baltic Lands, NY, Routledge, 2016.

O'Keeffe, Tadhg, «Frontiers of the Archaeological Imagination: Rethinking Landscape and Identity in Thirteenth-century Roscommon, Ireland», Landscapes, 2018, DOI: https://doi.org/10.1080/14662035.2018.1429718.

Pizarro Gomez, Francisco Javier, «Olivenza: modelo de transferencias arquitectónicas y urbanísticas entre España y Portugal», Quintana, 2010, nº 9, pp. 75-101. URL: https://minerva.usc.es/xmlui/handle/10347/6494.

Prado Sagrera, Nuria, «Dos castillos de tiempos de Sancho IV: Cumbres Mayores y Santa Olalla (Huelva): Notas sobre origen y función», Estudios de Historia y de Arqueología Medievales, 1994, nº 10, pp. 173-188.

Prado Sagrera, Nuria, «El castillo de Cumbres Mayores (Huelva): Una aproximación a la arquitectura militar de la segunda mitad del siglo XIII», Historia. Instituciones. Documentos, 1994, $\mathrm{n}^{\circ}$ 21, pp. 473-500. URL: https://revistascientificas.us.es/index.php/HID/article/view/5794. 
Rivas Quintero, Carlos Alberto; Fernández-Baca Galante, Rocío; Gamiz Aguilera, Remedios, «El patrimonio arquitectónico defensivo en la provincia de Huelva: protección, conservación y difusión», Ph Boletín, 2002, nº 40-41, pp. 206-213.

Rodríguez Casillas, Carlos Jesús, «Tipologia de las campañas militares ocurridas en la frontera luso-extremeña durante la guerra de sucesión castellana a la muerte de Enrique IV (1475-1479)», Revista Signum, 2010, vol. 11, nº 2, pp. 183-204. DOI: https://doi.org/10.21572/2177-7306.2011.V11.N2.10.

Rodriguez Picavea-Matilla, Enrique, «La Ganadaría en la economía de frontera: una aproximación al caso de la meseta meridional castellana en los siglos XIXIV», en Ayala Martínez, Carlos de; Buresi, Pascal; Josserand, Philippe (eds.), Identidad y representación de la frontera en la España medieval, siglos XI, Madrid, Casa Velázquez - Universidad Autónoma de Madrid, 2001, pp. 181-205.

Sousa, Armindo de «Fronteira e representação parlamentar na Idade Média Portuguesa», Revista da Faculdade de Letras. História, 1998, série I, vol. 15, pp. 54-61. URL: https://ojs.letras.up.pt/index.php/historia/article/view/5542.

Tamm, Marek, «A new world into words: The eastern Baltic region and the cultural geography of medieval Europe», en Murray, Alan (ed.), The Clash of Cultures on the Medieval Baltic Frontier, Surrey, Ashgate, 2009. URL: http://www.mgh-bibliothek.de/dokumente/b/b070194.pdf. (acedido em 24/04/2019).

Ventura, Leontina, «A fronteira luso-castelhana na Idade Média», Revista da Faculdade de Letras. História, 1998, série I, vol. 15, pp. 25-52. URL: https://ojs.letras.up.pt/index.php/historia/article/view/5540.

Ventura, Margarida Garcês, «Os coutos de homiziados nas fronteiras com o direito de asilo», Revista da Faculdade de Letras. História, 1998, série I, vol. 15, pp. 601-625, URL: https://ojs.letras.up.pt/index.php/historia/article/view/5572. 